This PDF is a selection from an out-of-print volume from the National Bureau of Economic Research

Volume Title: Technical Progress and Agricultural Depression

Volume Author/Editor: Eugen Altschul and Frederick Strauss

Volume Publisher: NBER

Volume URL: http://www.nber.org/books/alts37-1

Publication Date: November 1937

Chapter Title: Technical Progress and Agricultural Depression

Chapter Author: Eugen Altschul, Frederick Strauss

Chapter URL: http://www.nber.org/chapters/c7582

Chapter pages in book: (p. 1 - 32) 


\section{Technical Progress and Agricultural Depression}

Copyright 1937, National Bureau of Econumic Research, Inc.

\section{EUGEN ALTSCHUL and FREDERICK STRAUSS}

$T$ HE activities of the National Bureau of Economic Research have been directed, in the main, toward the improvement and analysis of the basic records of economic life. An adequate foundation of economic facts is essential to public administrators, to business men and to economists. Yet the work of a research agency should not be confined to fact-finding. It is proper that members of its staff should explore the implications of their data, formulating and testing hypotheses that interpret and unify the facts of economics.

This paper by Dr. Eugen Altschul and Dr. Frederick Strauss presents results secured in such a study. It is concerned with the interpretation of recent agricultural experience, rather than with the elaboration of the factual record of that experience. Employing Census data and other available material, the authors have advanced an hypothesis concerning the relation of technical progress to prolonged agricultural depressions of the type that has been so conspicuous a feature of the post-War economic situation.

This hypothesis presents in a new light the problems of agricultural change and of adjustment to the process of mechanization in agriculture. It should stimulate critical - study of the implications and possible consequences of the extensive use of machinery in farming operations. Its testing will call for careful appraisal of existing data and for the improvement of these data in important fields. If the main thesis of the authors is sound, it has an obvious and highly important bearing on the formulation of public policy in agriculture. The complete report of this investigation, which will appear in a forthcoming volume, will contain a fuller account of the evidence on which the authors base their hypothesis and more detailed analysis of the relations between business cycles, long-run and shortrun fluctuations in agriculture. In the meantime this pre- liminary statement of the argument is presented in the belief that it will prove stimulating to students of the problems facing American agriculture.

Dr. Eugen Altschul, the senior author of this monograph, is the former head of the Frankfurter Gesellschaft fuer Konjunkturforschung and editor of the German translation of the first volume of $W$. C. Mitchell's BusIness Cycles. Through the generosity of the Maurice and Laura Falk Foundation the National Bureau was able to bring him to the United States to make a study of agricultural depressions and business cycles. Shortly after his arrival in this country Dr. Altschul was invited to conduct courses on monetary theory and business cycles at the University of Minnesota. For the prosecution of his research work at the National Bureau, which he has carried on in conjunction with his teaching duties, Dr. Altschul secured the aid of Dr. Frederick Strauss, his former student at the University of Frankfort and economist of the ReichsKredit-Gesellschaft in Berlin. Since much of the work on Dr: Altschul's investigation has now been completed, the National Bureau has been able to release Dr. Strauss for a study of the changing balance between agriculture and industry, which the National Bureau is making in cooperation with the United States Bureau of Agricultural Economics.

\section{INTRODUCTION}

$\mathrm{B}$ ETWEEN the beginning of the nineteenth century and the World War agriculture in the Western World experienced two major depressions, both of long duration. One followed the Napoleonic Wars, the other appeared in the last quarter of the nineteenth century. The fact that these depressions lasted much longer than periods usually associzied with business cycles suggests that the long term fluctuations in agriculture constitute a peculiar type of 
disturbance and adjustment. Though it is difficult to find series adequately representing these long period disturbances, the available data indicate that the agricultural depression that started after the World War in the United States belongs to the same category as the two major depressions of the nineteenth century. The downward movement or low level of such series as the value of farm real estate, gross farm income and the ratio between the purchasing power of per capita farm income and non-farm income from 1920 to 1932 (Chart 1) provides evidence of a long run disturbance in the United States. It is true that in some years the declines were checked. Nevertheless, the period since 1920 appears homogeneous because, as we shall see, the causes of the disturbance persisted throughout.

Whatever the primary cause, long run depressions in agriculture appear as a reaction to an accelerated expansion in agricultural production, due to or in any case accompanied by a more or less sudden change in the technical conditions of production. The visible impulse to such expansions, which should not be identified with the primary cause, may come from different sources. Sometimes wars give the stimulus to a sudden overexpansion. The $\mathrm{Na}$ poleonic Wars and the World War had apparently such effects. Sometimes an accelerated industrial development and a rapid growth in population stimulate a rapid increase in agricultural production. This happened in the period preceding the agricultural depression of the last quarter of the nineteenth century, when the cultivation of large areas of virgin land led to a tremendous expansion in grain production.

It is the combined effect of different factors that brings about in a specific historical situation a long period depression, but it is impossible satisfactorily to separate the several factors at work or to determine their relative importance. We face these difficulties also in analyzing the recent depression. In this case, however, one feature stands out from the rest, namely, rapid mechanization and its consequences.

The aim of mechanization, like that of any technical improvement, is to reduce cost. In its realization agriculture faces particular difficulties. Once mechanization has been introduced on a large scale, the farmer has little choice in selecting the size of his farm and his equipment. Mechanization leads to an increase in output and a reduction in cost. Therefore farmers not equally equipped with capital can no longer compete with the more progressive farmers. This does not, however, lead to the immediate withdrawal from production of farmers who cannot reduce costs by utilizing new methods of production.

This constitutes the first phase of the agricultural depression, in which only the less efficient farmer is affected

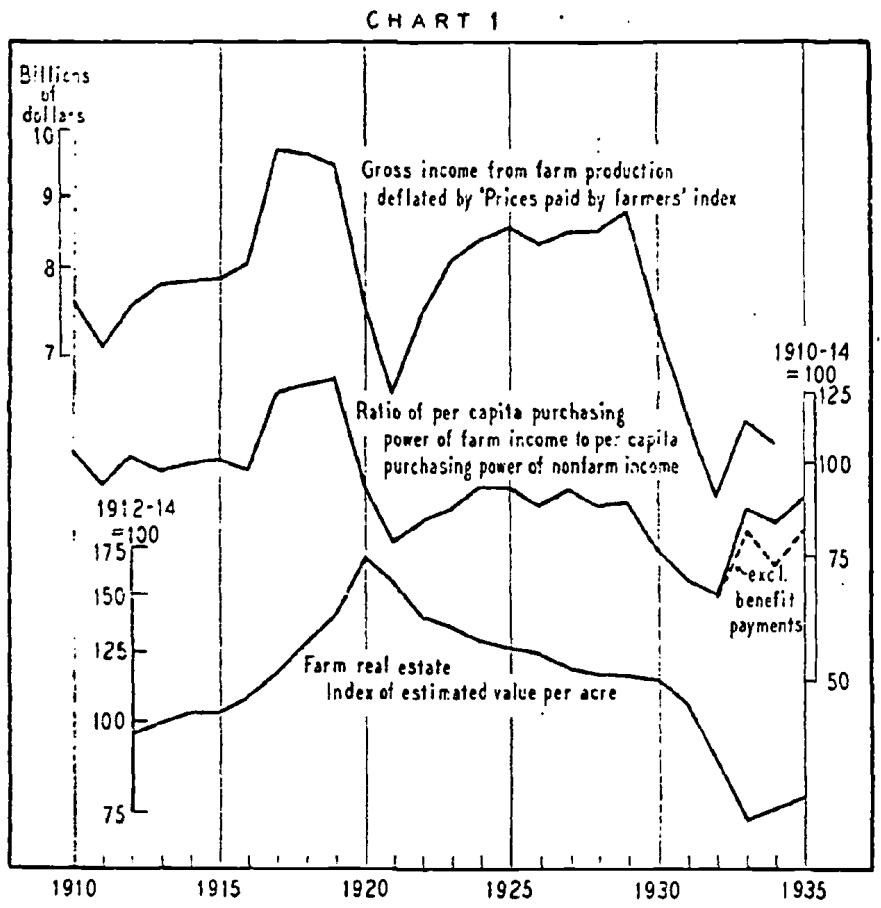

while the farmer who can utilize new methods of production gains differential profit or at least normal profit. The cost advantages of the mechanized farms determine how long the effects of falling prices can be compensated. Until this point is reached both categories of farmers will expand production: the more efficient because it is profitable, the marginal in order to meet cash expenses. The process of elimination of marginal producers at this stage differs from that in industry only in degree. But when with expanding production the price fall persists, highly mechanized farms begin to lose their cost advantage. Unyielding overhead becomes a barrier to the adjustment of cost to falling prices. The burden of overhead costs can become so heavy that these farms may turn to less mechanized technique.

Since the advantages of mechanized farms may temporarily disappear and the disadvantage of unmechanized farms may at times be turned into relative advantages, the elimination of marginal farmers does not present a continuous process. Before these farmers are wiped out they will make every effort to compensate the effect of a destructive price decline by expanding production, particularly if a shift to less disturbed branches is impossible or highly restricted. The readjustment may therefore be retarded for years.

Only a detailed analysis, which must be reserved for a forthcoming book, can show to just what extent the peculiarities of agriculture determine the process of adjustment to new conditions of production. Here we can call attention only to a few points.

The difficulties of adjusting the supply of agricultural products to changing conditions of production and the low 
elasticity of demand for agricultural products together determine the main course of the depression. The disturbances resulting from sudden changes in the technique of production are of long duration because they tend to cause shifts in the whole structure of the agricultural supply. 1. if rbances emanating from demand are in general of shl run character.

Thus fluctuations in agriculture cover a great variety of disturbances. They are complex and differ greatly from branch to branch. Only with some limitations can we speak about the situation in agriculture as a whole. The process of adjustment to changed market conditions, being affected by specific conditions of production and by specific elasticities of demand for the individual agricultural products, is different in different branches of agriculture.

In this Bulletin we discuss two leading agricultural products, wheat and cotton. Wheat was chosen for two principal reasons: (1) technical changes are more advanced in the production of wheat and their consequences are more far-reaching than in any other branch of farming, (2) wheat is one of the most important sources of farm income, and its price influences greatly the prices of other grains and of farm land, and so affects large agricultural groups. Cotton was chosen because its analysis reveals certain peculiarities that are in contrast to the disturbances and fluctuations in wheat. Mechanization has not played the same role in cotton farming that it has in wheat production. The discussion of cotton brings out the importance of a number of other factors that have influenced recent agricultural developments in this country. It should be noted, however, that although reference is made to certain of these other factors, the present analysis does not describe the agricultural depression in its totality; it is - limited to a characterization of its outstanding features as a long run phenomenon.

We start with the analysis of mechanization as the most characteristic factor of modern technical progress in agriculture. We then turn to some additional factors which modified the influence of technical progress and which must be taken into consideration if we want to understand the peculiar effects and repercussions of technical change.

\section{The Role of Mechanization in Wheat Farming}

Arable farming, particularly wheat production, was characterized during the post-War period by a radical d $\left(\left(f_{i} \mathrm{e} e\right.\right.$ in technique. The consequent expansion in prodítion resulted in (1) excess supply, (2) shifts in farm production and organization. Wheat does not tell the whole story of the agricultural depression, yet it reveals with especial clarity the outstanding characteristics of the depression, namely, severity and long duration. We consider first: (a) technical conditions of production; (b) ex- pansion of production; (c) mechanization and its relation to the size of farms; (d) changes in farm organization; (e) implications and probable future development. ${ }^{3}$

\section{a. Technical conditions of production}

From the beginning of the twentieth century to the outbreak of the World War American agriculture developed fairly steadily. The continuous shifts in farm production and organization did not greatly affect the structure of American farming, since under the prevailing market conditions all kinds of producers could exist. Though wheat acreage and production were rising during the years immediately preceding the War, the level of production was still about the same as it had been in the decade 1900-09. A western movement of wheat farming was noticeable. We do not know whether the expansion in wheat acreage might have continued in any event. The technical improvement of the gasoline tractor and the combine would have contributed to such expansion even if war had not broken out, and would have led to major changes in farm organization. As we shall show later, a large part of the increase in mechanization and production occurred after the War, when the specific war conditions no longer existed. The coincidence of improvements of farm machinery and the rise in wheat prices during the War accelerated the change in production methods. The price increase was a strong stimulus to expansion of production, which in turn would hardly have been possible without the use of mechanical power unless acreage devoted to other farm products had been curtailed. But for such a curtailment there was scarcely any motive, for the prices of other farm products were increasing simultaneously at similar rates. Though expansion in wheat acreage was due partly to temporary cultivation in sections that had previously been converted from wheat production to other uses, ${ }^{2}$ the far greater part seems to have been due to shifts into districts formerly considered unsuitable for arable farming. That the increased use of tractors and combines is closely related to the expansion of wheat acreage seems to be the prevailing opinion of experts. According to the Department of Agriculture, "expanding wheat acreages ... although caused primarily by mechanical power, had been influenced to a very marked degree by power equipment. Perhaps the chief influencing factor of equipment was the combined harvester-thresher". The importance of this factor is indicated by the record of tractor production and sales in the United States (Table 1).

${ }^{1}$ The effects of the World War can be evaluated only after disentangling the basic tendencies in American agriculture before and after the War.

${ }^{2} \mathrm{Cf}$. Joseph S. Davis, Wheat and the $A A A$ (Brookings Institution, 1935), p. 6.

${ }^{3}$ Cf. Yearbook of Agriculture, 193?, p. 419, 
TA B L E 1

Nember of Gasoline Tractors Manufactured and Sold VNiTED STATES, 1909-1936'

\begin{tabular}{rrrrrr} 
BAALFACTLED & \multicolumn{5}{c}{ SOL D } \\
1309 & 2,000 & 1916 & 27,819 & 1925 & 118,739 \\
1910 & 4,000 & 1917 & 49,504 & 1926 & $122,9+0$ \\
1911 & 7,000 & 1918 & 96,470 & 1927 & 155,843 \\
1912 & 11,500 & 1919 & 136,162 & 1928 & 99,820 \\
1913 & 7,000 & 1920 & 162,988 & 1929 & 155,310 \\
1914 & 15,000 & 1922 & 100,092 & 1930 & 128,265 \\
1915 & 21,000 & 1923 & 115,040 & 1931 & 40,200 \\
1916 & 30,000 & 1924 & 96,639 & 1935 & 132,848 \\
& & & & 1936 & 179,236
\end{tabular}

${ }^{1}$ Figures for 1909-17 are for wheel and tracklaying types manufactured. Figures for 1916-27 are for the same types sold in the United States; see Yearbook of Agriculture, 1930, p. 10t0. Cf. W. N. Hurst and L. M. Church, Power and Machinery in Agriculture, U. S. Department of Agriculture, Misc. Publ. No. 157, April 1933, p. 31. Figures for 1935 and 1936 are from Manufacture and Salc of Farm Equipment and Related Products, 1935, U. S. Department of Commerce, Bureau of the Census, 1936 and 1937. Figures for 1931 are the number manufactured minus exports.

"During 1920-29 the sales of industrial tractors constituted only' 16 per cent of total tractor sales (all types) in the United States (based upon analysis of Census data made by H. L. Boyle of the International Harvester Company).

Had the extension of acreage and production stimulated by the War been made with the old production methods, American wheat farming would hardly have undergone the major changes actually experienced. To bring under cultivation those areas which contributed most to the increase in production required a revolutionary change in method.

Internal combustion engines had already been introduced on farms in the first decade of the twentieth century. Sooner or later they would have been perfected. It is diffcult to say to what extent high prices for farm products and shortage of farm labor hastened the perfection and introduction of the tractor. The fact that the light-weight highspeed gasoline tractor was introduced so rapidly between 1915 and 1920 is, however, significant. It facilitated a development of the Great PIains that would not have been possible with animal power." Once the start with mechanized, lower cost methods had been made in the sub-humid districts, further application was to be expected, though the motives differed greatly at different periods. During the War, and in less degree from 1924 to 1928 , the price situation stimulated the mechanization of farms. After the price collapse in 1920, wheat farmers found that only by mechanized methods could costs be reduced to a point where production became profitable. That is, wheat

'Cf. R. U. Blasingame, Relation of Mechanical Progress in Agriculture to Land Utilization and Land Policy, in Gencral Conditions and Tendencies Influencing the Nation's Land Requirements, Part I, Supplementary Report of the Land Planning Comnittee to the National Resources Board (Washington, $D$. C., 1936), p. 39, farmers mechanized production either in order to obtain differential profits or to make production profitable at all.

The improvement of the tractor and the combined harvester-thresher made it possible to reduce costs, particularly in the states that had increased production notably during the War. According to the Census figures the number of tractors in the eight most important Great Plains states increased from 82,000 in 1919 to 274,000 in 1929. The combined harvester-thresher was introduced even more rapidly. In Kansas, for instance, the number of combines in operation increased from a few machines in 1918 to 8,300 in 1926 , and to about 20,000 in 1931. Similar increases are to be noted in other sub-humid wheat producing states such as Montana, where in $1930^{\circ}$ some 6,000 harvester-threshers were in use. The number of tractors used in Montana rose, between 1925 and 1930, from 8,000 to 20,000 .

\section{b. Expansion of production}

The primary consequence of this far-reaching change in method was a rapid expansion of acreage and a corresponding rise in production (Chart 2). Most striking was the expansion in Montana, where wheat acreage continued a sharp upward trend already marked before the War. Acreage harvested increased from $1,005,000$ acres in $1910-14$ to $2,528,000$ acres in $1915-19,3,361,000$ acres in 1920-24, and 3,935,000 acres in 1925-29, with a peak of $4,419,000$ in 1929. The production figures show clearly that the increase was especially great after the War. The highest pre-War level (1910-14) of 22,189,000 bushels was surpassed by about one-half during the $W$ ar and was doubled during 1920-24, a peak being reached in 1927 with $81,713,000$ bushels.

The leading wheat state, Kansas, rapidly increased its acreage between 1910 and 1914 . During the $W$ ar acreage was not further expanded, but rose greatly in 1919. Though the level then reached was not maintained, in 1920-24 acreage was more than 40 per cent above 1910-14. Thereafter a further advance occurred, from $8,755,000$ acres in 1925 to the record high of 13,623,000 acres in 1931. Production show's essentially the same features: despite extreme fluctuations in yield the gradual rise to the record level of 1928-31 is striking.

In five important winter wheat states (Kansas, Nebraska, Oklahoma, Texas, Colorado) the rise was similar. From 10.4 million acres in 1910, acreage increased continuously to 24.5 million in 1919. It declined from 1919 to 1925 , but the level during 1920-25 was still about 50 per cent above the pre-War and over 15 per cent above the IVar level. The subsequent rise was like that in Kansas.

In all these regions, with topographic and climatic con${ }^{5}$ Cf. Yearbook of Agriculture, 1932, p. 419.

'E. A. Starch, Farm Organization as Affected by. Mechanization; Montana Agricultural Experiment Station, Bull. 278, May 1933. 


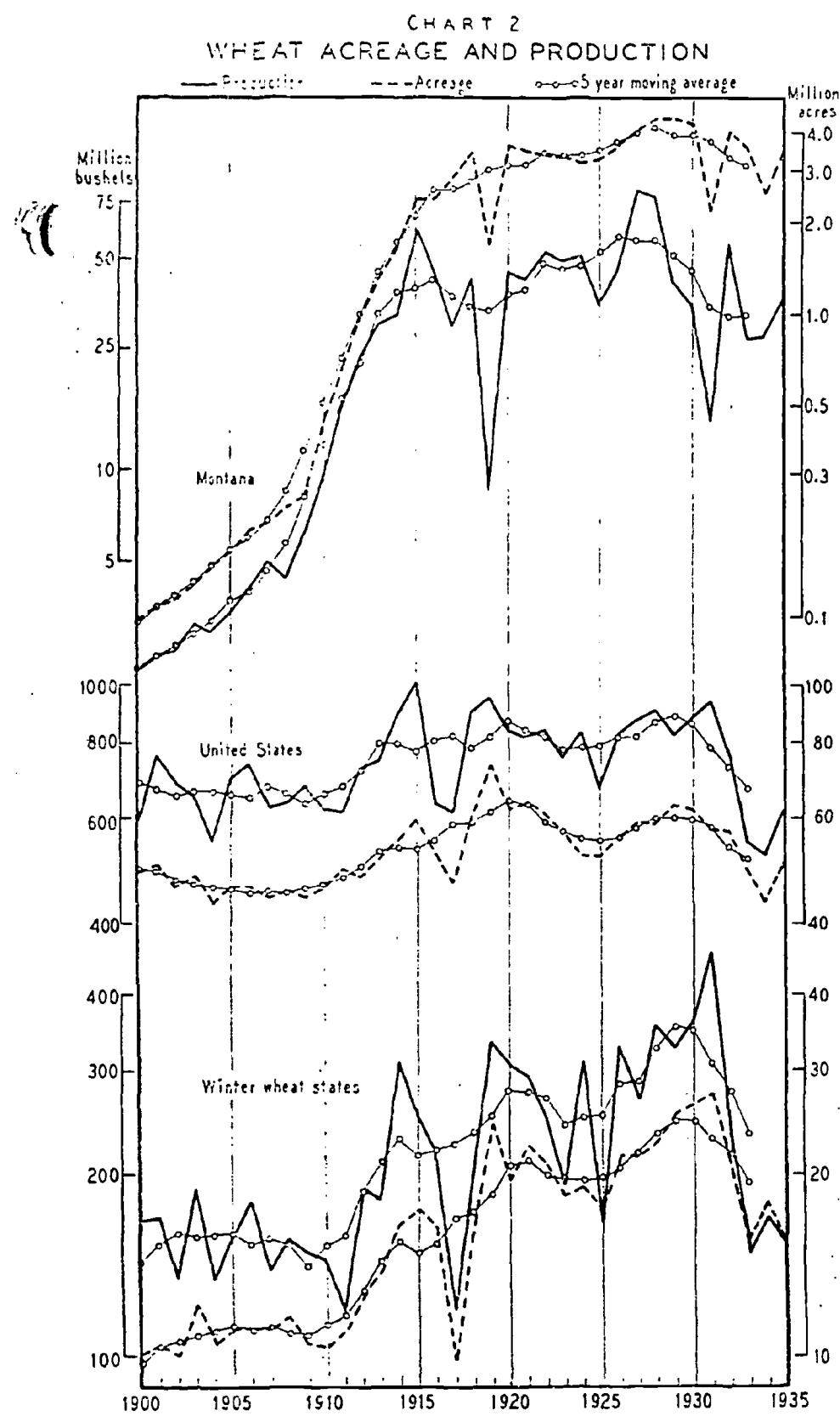

ditions suitable for mechanized methods, acreage and production attained new high levels between 1928 and 1931. This record stands in sharp contrast to those areas that could not introduce large scale mechanized methods. Though acreage and production in the latter areas were increased during the War because of high prices, notable decreases took place throughout the post-War period. These opposing tendencies are clearly revealed by a comparison of selected counties in different areas. In 1,940 counties located in the eastern and southern sections of the United States, acreage harvested declined 32 million acres from 1919 to $1929 ; 1,130$ counties, most of them in the Great Plains, reported an increase of 33 million acres. Though the years to which these figures refer, and the fact that they cover all kinds of crops, limit their signifcance with respect to the general wheat situation, the direction of the movement is clear. During the same decade wheat acreage harvested decreased 20 per cent in the East and South and increased 40 per cent in the Great Plains. The reason for the increase in the Great Plains is largely the superiority of mechanized methods, as O. E. Baker of the Department of Agriculture states. ${ }^{7}$ The land, the crops grown, and the large farms of the Great Plains are particularly suited to power machinery.

The increase of acreage and production in states where large scale mechanized methods could be applied, and decrease in sections that had mainly to use the older methods, determined total wheat acreage and production in the United States. Wheat acreage rose from 1910, with a break in 1916-17, to a record high in 1919. The peak, 73.7 million acres in 1919, surpassed the pre-War average (1910-14)) of 50.3 million acres by nearly one-half. Though in the immediate post-War years acreage declined (except in 1921) until 1925 (52.4 million acres), the level as expressed in the five-year average for 1920-24 was almost 20 per cent above that of 1910-14. The five-year moving averages in Chart 3 show that acreage fluctuated about the 1920-24 level until 1932, as did total production.

The United States may have led in the application of mechanized methods, but the effects of mechanization on the expansion of wheat acreage and production were by no means peculiar to this country. Acreage and production increased, in Canada, Argentina and Australia as well. Canada, for which figures on mechanization are available, is typical. The use of tractor and combine apparently started there some years later than in the United States. During the War this factor seems to have been only of minor significance. From 1921 to 1931, however, the number of tractors on farms in the Canadian West increased from 38,000 to 81,000 . The number of combined harvester-threshers rose rapidly, especially after 1925 , over 3,500 being sold in each of the years 1928 and 1929.

A remarkable feature of the Canadian situation is that wheat production decreased sharply during the $W$ ar and started to rise only at its end. In 1918 and 1919 production was still below the pre-War level. From then on, with the exception of a break in 1924, the trend was steeply upward until 1928. The level during 1920-24 was more than 30 per cent above the War level of 1915-19, and during the next five years production increased again at about the same rate. Total production in Canada, Argentina and Australia together (Charts 3 and 4 ) is ${ }^{7}$ The Future Need for Farm Land (Address, Iowa State College, February 9, 1934), p. 22.

'A. Stewart, The Economy of Machine Production in Agriculture (Ottawa, 1932). 
CHART 3

WHEAT PRODUCTION

ama- 5 year moving average

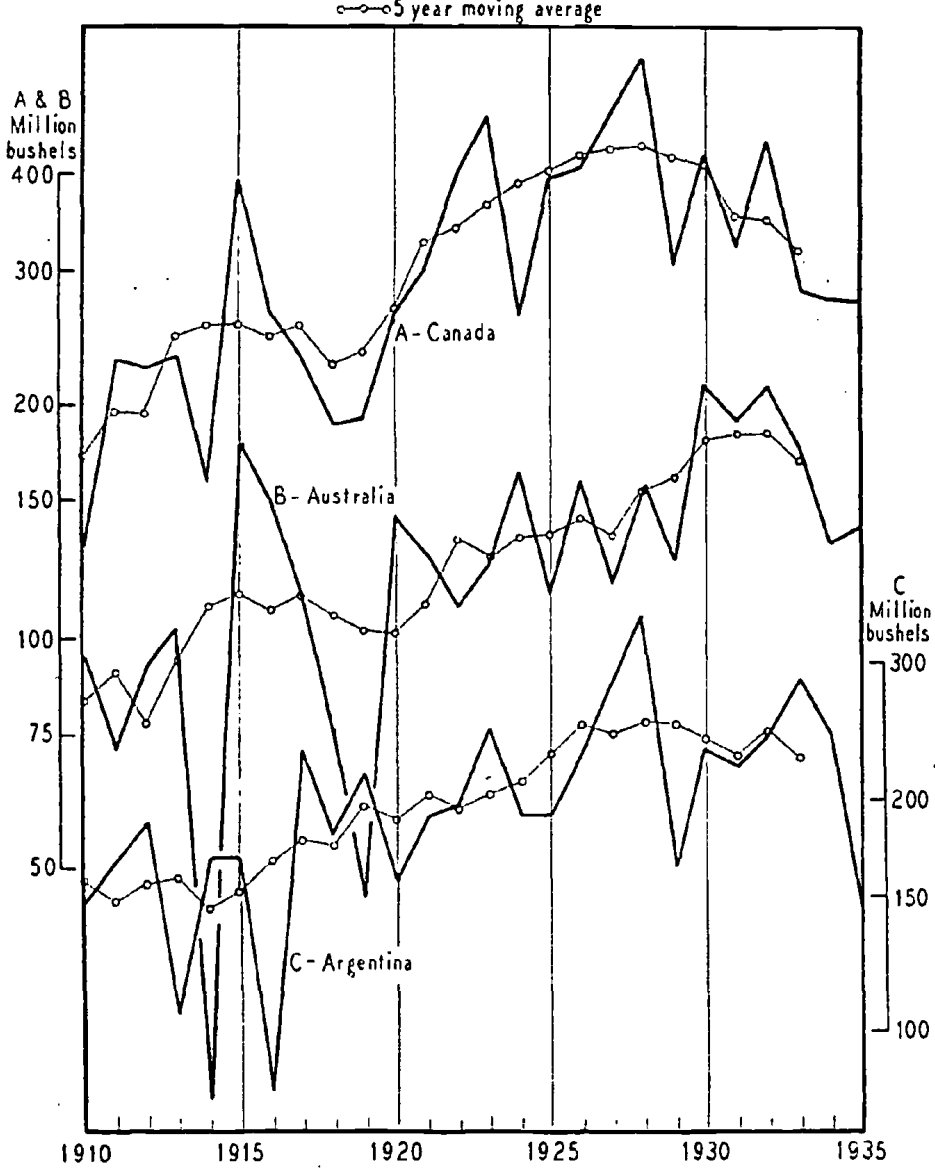

characterized by a sharp rise from 1919 to 1928, interrupted only in 1924. The War level, 1915-19, was about one-fourth above that of 1910-14; in each of the two following five-year periods the level rose more than one-fifth ( 23 per cent and 21 per cent, respectively).

Chart 4 gives an impression of the changes in the contributions of the various groups of countries to total world production (excluding Russia and China). The end of the World War separated two periods of development. European production (excluding Russia) declined sharply from a high of 1,366 million bushels in 1911 to a low of 865 million bushels in 1917, or from a pre-War average (1910-14) of 1,262 million bushels to the War average (1915-19) of 979 million. Combined production of the main exporting countries, United States, Canada, Argentina and Australia, fell off sharply in 1916, then started to rise, and in 1918 surpassed the 1914 level. Production increased continuously, except during 1924 and 1925, until 1928. European production started its rise at the end of the $W$ ar and, if we disregard extreme crop fluctuations, continued to the record level of 1933. World production (excluding Russia and China) reached its peak of 3,995 million bushels in 1928, an increase of more than 40 per cent over 1919 . To avoid implications suggested by ac-

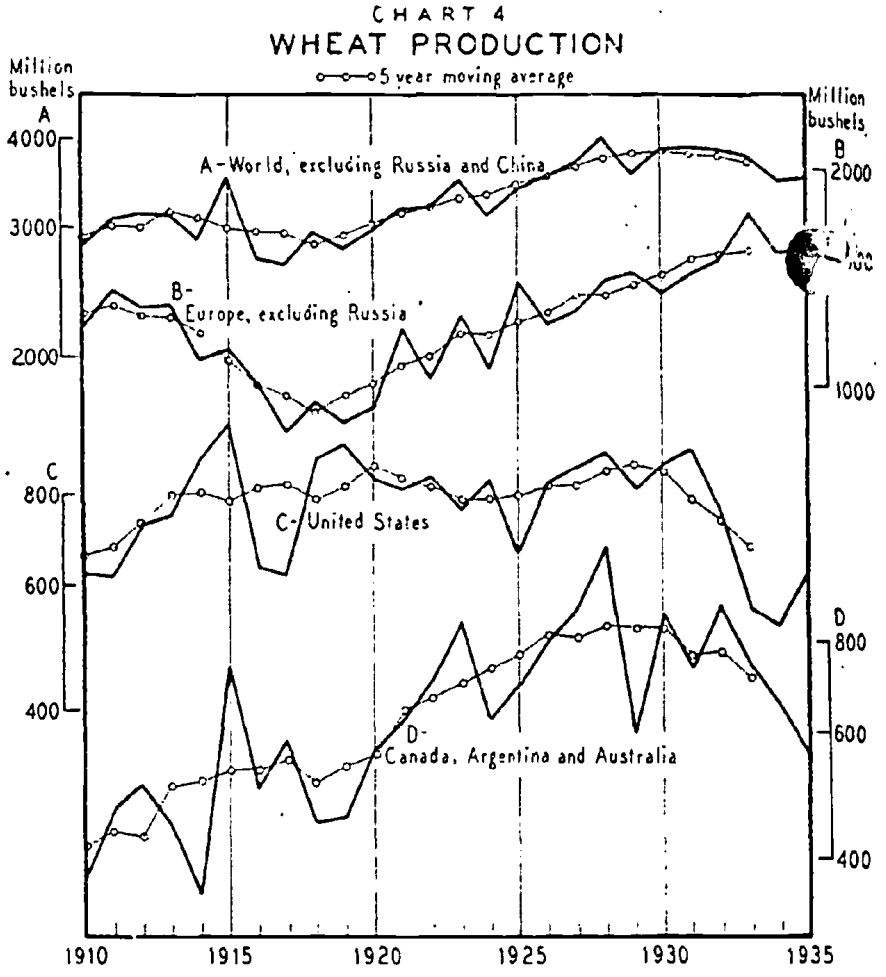

cidental factors in any one year, the five-year low at the close of the War may be compared with the five-year high centering about 1930. From 1916-20 to 1928-32 world production (excluding Russia and China) rose from 2,824 million to 3,826 million bushels, or 35 per cent. Of this increase, 39 per cent was due to expansion of production in the four main exporting states and 49 per cent to the increase in European production (excluding Russia). The sharp increase of European wheat production in a period when the exporting countries continued to expand their output contributed materially to the severity of the depression.

Undoubtedly, these countries expanded their production because they expected the conditions existing during or immediately after the War to continue. But after market conditions had changed, the readjustment became extremely difficult owing to the very methods used in expanding production.

\section{c. Mechanization and its relation to the size of farms}

Large scale mechanized methods as utilized in the main wheat producing districts of the United States and the other exporting countries had a two-fold effect: (1) the post-War level of acreage and production was attainged in a very short period, (2) the problems of adjustme 40 changed market conditions were rendered more difficult by the very nature of mechanized production.

Falling grain prices placed pressure upon wheat farmers (so far as they could not shift to other branches of agriculture) to expand their production, in order to be able to meet cash expenses. This pressure was present during 
most of the post-War period. Table 2 indicates to what extent the disparity in the movement of certain cash expenses and of wheat prices may increase the amount of wheat required to cover those expenses.

$$
\text { TA B LE } 2
$$

Tades per Farm and Amount of Wheat Required to MeEt Tax Payments ${ }^{2}$

$\begin{array}{cccc}\text { PA.TES } & \begin{array}{c}\text { PRICE OF } \\ \text { WHEAT }\end{array} & \begin{array}{c}\text { BUSHELS OF } \\ \text { WHEAT }\end{array} & \begin{array}{c}\text { ACRES OF } \\ \text { WHEAT }\end{array} \\ \$ 119.33 & \$ 2.18 & 54.7 & 2.7 \\ 13 \$ .28 & 2.52 & 54.9 & 4.2 \\ 162.85 & 1.30 & 125.3 & 7.0 \\ 16+.26 & 1.50 & 109.5 & 9.5 \\ 167.06 & 1.12 & 149.2 & 7.7 \\ 165.66 & 0.80 & 207.1 & 11.6 \\ 157.94 & 0.43 & 367.3 & 12.5 \\ 118.46 & 0.38 & 311.7 & 15.2\end{array}$

$\begin{array}{lcc}1932 & 0.38 & 311.7 \\ & 118.46 & \end{array}$ 1933, p. 97. The example refers to the number of bushels of wheat and of crop acres required to meet taxes on an Ohio farm of average size (98.1 acres).

There are, however, important differences in the possibilities of readjustment to such changes in market conditions between farms operating with older production methods and large scale mechanized farms. Non-mechanized farms can more easily adjust their crops to the relative advantages of various farm products. But highly mechanized wheat farms have in general no choice; they must continue to grow wheat. Large scale farm machinery requires a certain minimum acreage in order to be profitable. Many cost analyses show that once a farm business is organized on the basis of a given investment in machinery, curtailing production takes away the cost advantages of mechanization. This may be illustrated by the examples cited in Table 3. The figures there given indicate use of a 10-foot combine on 600 acres costs nine cents more per - acre than on 800 acres; on 400 acres costs are increased one-fourth. Using a 16-foot combine on 1,200 acres would reduce costs to $\$ .99$; costs per acre would increase 60 per cent if acreage were curtailed to 400 acres, for instance.

TABLE 3

Cost per acre in Harvesting Wheat with Combine Harvesters ACRES HARVESTED FOR Plots OF Different Size ${ }^{2}$

AN NUALLX
100
200
300
400
500
600
700
800
900
1,000
1,100
1,200

$\begin{array}{ccc}10 \text { foot } & 12 \text { foot } & 16 \text { foot } \\ \$ 3.08 & \$ 3.58 & \$ 4.33 \\ 1.94 & 2.19 & 2.51 \\ 1.56 & 1.73 & 1.90 \\ 1.37 & 1.50 & 1.60 \\ 1.26 & 1.36 & 1.42 \\ 1.18 & 1.26 & 1.30 \\ 1.13 & 1.20 & 1.21 \\ 1.09 & 1.15 & 1.14 \\ \ldots \ldots . & 1.11 & 1.09 \\ \ldots \ldots . & 1.08 & 1.05 \\ \ldots . . & \ldots \ldots . & 1.02 \\ \ldots . . & \ldots . . & .99\end{array}$

${ }^{2}$ University of Minnesota, Bull. 266, May 1930, G. A. Pond and L. P. Basset, Cost of Combine Harvesting in Minnesota, p. 17.
The figures quoted may be extreme, but they indicate the dilemma that many farmers face, i.e., either to produce big crops by fully utilizing their farm machinery or to lose their cost advantages. Experts believe that mechanized farms, by taking advantage of cost reduction by acreage expansion, were able to maintain profits until about 1930-31. At that time about one-third of the hard winter wheat one-fifth of the spring wheat and a smaller amount of soft winter wheat were harvested with the combine. ${ }^{20}$ The preceding statements do not mean, of course, that only farmers using combines made profits, while wheat farmers operating with old methods faced ruin.; or that all mechanized farms could resist depression, and others could not. Indebtedness, reserves, and numerous other items are important. Other things being equal, however, the cost advantages of large scale mechanized farms meant economic superiority for this type of wheat farmer from 1920 until about 1930. Consequently, we would expect that during this period the farms less efficient in this respect would have been eliminated. This hypothesis will be examined later.

Highly mechanized wheat farms do not retain their advantage under all market conditions. The nature of the. costs implies that under certain conditions they may lose it. The power to resist depression is highly affected by the relation of cash income to cash outlays. Table 4, based on

${ }^{\circ}$ Cf. e.g., Yearbook of Agriculturc, 1932, p. 415.

${ }^{20}$ See H. R. Tolley and A. P. Brodell, The Role of Machinery in the Development of the Agriculture of the United States, U. S. Department of Agriculture, Bureau of Agricultural Economics (mimeographed report), 1930.

$$
\text { TABLE } 4
$$

Calculated Relative Returns to Operators on 200 Acre Horse-Power Farms and 500 ACre Tractor-Power Farms in Kansas at VARIOUS PRICES for Wheat ${ }^{1}$

Wheat at $\$ 1.00$ per Bushel Horse Farms Tractor Farms

Value per acre of operator's share $\quad \$ 7.25 \quad \$ 7.25$

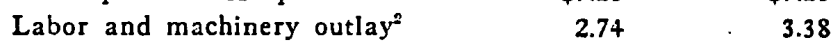

Net value per acre $\quad 4.51 \quad 3.87$

Total net for acreage operated $902.00 \quad 1,935.00$

Wheat at $\$ .60$ per Bushel

Value per acre of operator's share $\quad 4.35 \quad 4.35$

$\begin{array}{lll}\text { Labor and machinery outlay" } & 2.74 & 3.38\end{array}$

$\begin{array}{llr}\text { Net value per acre } & 1.61 & .97\end{array}$

Total net for acreage operated $\quad 322.00 \quad 485.00$

Wheat at \$.40 per Bushcl

Value per acre of operator's share $\quad 2.90 \quad 2.90$

Labor and machinery outlay ${ }^{2} \quad 3.74 \quad 3.38$

Net value per acre $\quad .16 \quad-.48$

Total net for acreage operated $\$ 32.00 \quad-\$ 210.00$

${ }^{1} \mathrm{C}$. L. Holmes, Farm Production Costs as Affected by Mechanical Farm Equipment, U. S. Departrient of Agriculture, Bureau of Agricultural Economics (mimeographed report), November 30, 1931.

"Machinery outlay equals actual cost of fuel, oil and repairs plus calculated depreciation. 
TAB L E 5

CONCFNTRATION OF CROP LAND, 1909-1934

CHANGES IN CROP ACREAGE, ${ }^{\prime}$ CLASSIFIED ACCORDING TO SIZE OF FARMS IN WHICH ACREACE WAS HEL.D

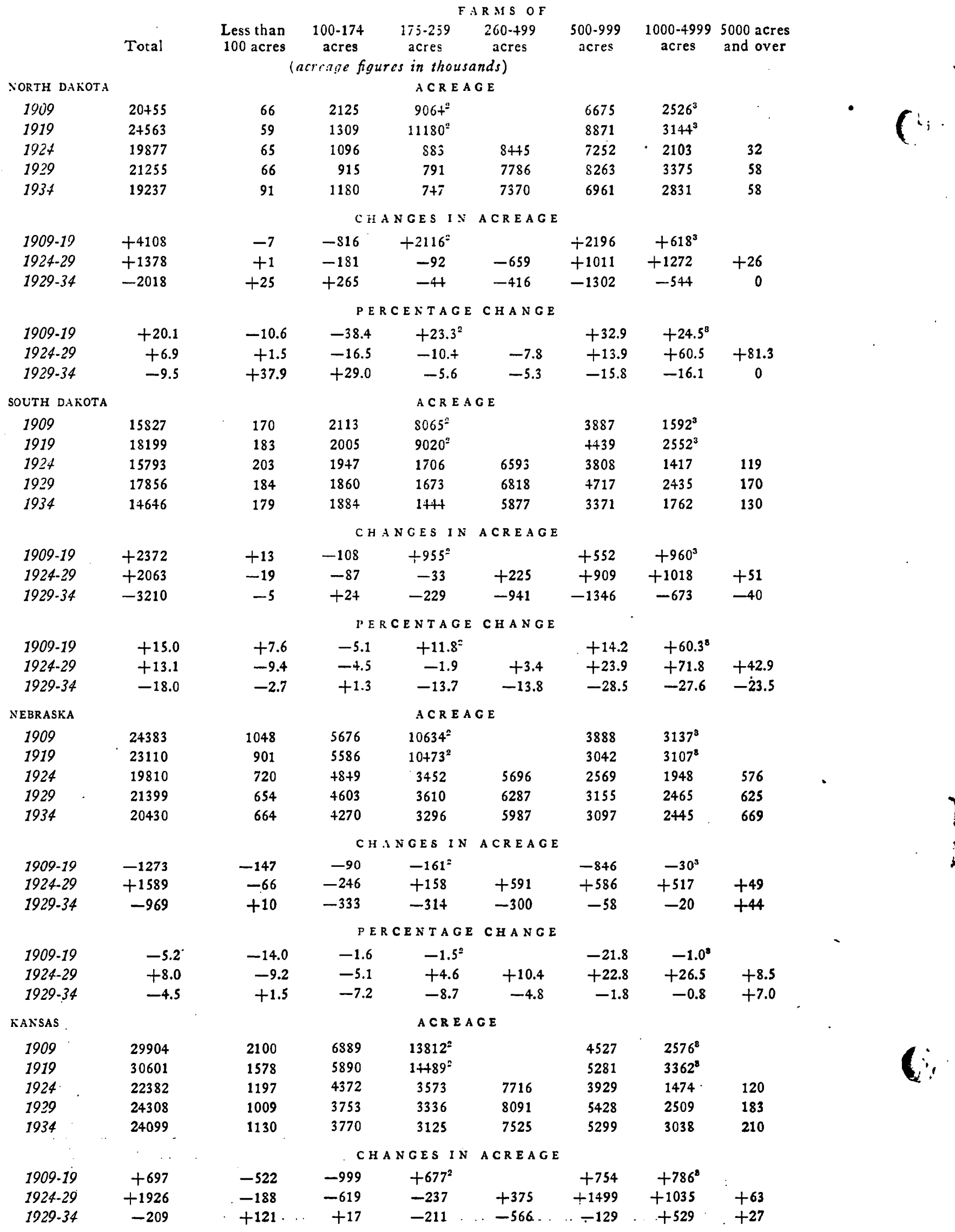


TABLE $S$ (continued)

\begin{tabular}{|c|c|c|c|c|c|c|c|}
\hline \multirow[b]{2}{*}{ Total } & \multicolumn{7}{|c|}{ FAR $M S O F$} \\
\hline & $\begin{array}{l}\text { Less than } \\
100 \text { acres }\end{array}$ & $\begin{array}{c}100-174 \\
\text { acres }\end{array}$ & $\begin{array}{c}175-259 \\
\text { acres }\end{array}$ & $\begin{array}{c}260-499 \\
\text { acres }\end{array}$ & $\begin{array}{c}500-999 \\
\text { acres }\end{array}$ & $\begin{array}{c}1000-+999 \\
\text { acres }\end{array}$ & $\begin{array}{l}5000 \text { acres } \\
\text { and over }\end{array}$ \\
\hline
\end{tabular}

(n)

KAXSAS

$1900-19$

19?7-29

1929-34

$+2 . \hat{3}$

$+\$ .6$

PERCENTAGE CHANGE

Moxtaxi

\section{9}

1919

1924

1929

1934

$$
\begin{array}{rr}
-2+.9 & -14.5 \\
-15.7 & -14.2 \\
+12.0 & +0.5
\end{array}
$$

$$
+4.9=
$$$$
-6.6
$$$$
\begin{array}{r}
+4.9 \\
-7.0
\end{array}
$$$$
\div 16.7 \quad+30.5^{3}
$$$$
\div 35.2+70.2+52.5
$$$$
-6 . \hat{3}
$$$$
-2.4
$$$$
+21.1+14.8
$$

A CREAGE

$\begin{array}{rrrrrrr}81 & 61+ & 924^{2} & & 599 & 1422^{3} & \\ 140 & 661 & 3777^{2} & & 3109 & 3320^{3} & \\ 93 & 360 & 220 & 1850 & 2027 & 1445 & 423 \\ 97 & 303 & 197 & 1309 & 2358 & 2984 & 593 \\ 131 & 3+3 & 200 & 1230 & 2008 & 2649 & 600\end{array}$

$\begin{array}{ll}1909-19 & +7367 \\ 192 \div-29 & +1425\end{array}$

1929-34 -681

+59
+4
+34

CHANGES IN ACREAGE

$\begin{array}{ccc}+47 & +2853^{2} & \\ -57 & -23 & -541\end{array}$

$++0$

$+3$

$-79$

$\begin{array}{rrr}+2510 & +1898^{3} & \\ +331 & +1539 & +170 \\ -350 & -335 & +7\end{array}$

$\begin{array}{lr}1909-19 & +202.4 \\ 1927-29 & +22.2 \\ 1929-37 & -8.7\end{array}$

+72.8
+4.3
+35.1

PERCENTAGE CHANGE

COLORADO

$\begin{array}{ll}1909 & 4302 \\ 1919 & 77+5 \\ 1924 & 5948 \\ 1929 & 6750 \\ 1934 & 7242\end{array}$

$\begin{array}{lr}1909-19 & +3443 \\ 1924-29 & +802 \\ 1929-34 & +492\end{array}$

$\begin{array}{rr}1909-19 & +80.0 \\ 1924-29 & +13.5 \\ 1929.34 & +7.3\end{array}$

WASHINCTON

$\begin{array}{ll}1909 & 6373 \\ 1919 & 7129 \\ 1924 & 3263 \\ 1929 & 3659 \\ 1934 & 3733\end{array}$

$\begin{array}{rr}373 & 979 \\ 501 & 1022 \\ 409 & 790 \\ 401 & 757 \\ 430 & 845\end{array}$

$\begin{array}{rrr}+7.7 & +30 \text { S. } & \\ -15.8 & -10.5 & -29.2 \\ +13.2 & +1.5 & -6.0\end{array}$

$\begin{array}{rrr}++19.0 & +133.5^{3} & \\ +16.3 & +106.5 & +40.2 \\ -1+.3 & -11.2 & +1.2\end{array}$

\section{A CREAGE}

\begin{tabular}{lcrrrr}
\multicolumn{7}{l}{ A C R E G E } \\
979 & $1457^{2}$ & & 558 & $936^{3}$ & \\
022 & $2909^{2}$ & & 1734 & $1580^{3}$ & \\
790 & 383 & 1853 & 1492 & 838 & 183 \\
757 & 394 & 1760 & 1808 & 1445 & 186 \\
845 & 407 & 1946 & 1911 & 1532 & 173
\end{tabular}

\section{CHANGES IN ACREAGE}

\begin{tabular}{rrrrrrr}
+128 & +43 & $+1452^{2}$ & \multicolumn{5}{c}{+1176} & $+644^{3}$ \\
-8 & -33 & +11 & -93 & +316 & +607 & +3 \\
+29 & +88 & +13 & +186 & +103 & +87 & -13
\end{tabular}

PERCENTAGE CHANGE

\begin{tabular}{|c|c|c|c|c|c|c|c|c|}
\hline \multirow[b]{2}{*}{$1909-19$} & \multirow[b]{2}{*}{+756} & \multirow[b]{2}{*}{+245} & \multicolumn{3}{|c|}{ CHANGES IN ACREAGE } & \multirow[b]{2}{*}{+157} & \multirow[b]{2}{*}{$+500^{3}$} & \multirow[b]{3}{*}{+28} \\
\hline & & & -120 & $-26^{2}$ & & & & \\
\hline $1924-29$ & +396 & -4 & -18 & -9 & -59 & +41 & +417 & \\
\hline \multirow[t]{2}{*}{$1929-34$} & +74 & +91 & +28 & +11 & -19 & -35 & +5 & -8 \\
\hline & \multicolumn{8}{|c|}{ PERCENTAGE CHANGE } \\
\hline $1909-19$ & +11.9 & +54.6 & -17.1 & $-1.5^{2}$ & & +9.2 & $+27.5^{\mathrm{s}}$ & \\
\hline $1924-29$ & +12.1 & -0.7 & -5.8 & -4.9 & -10.4 & +5.2 & +52.8 & +35.9 \\
\hline $1929-34$ & +2.0 & +16.6 & +9.6 & +6.3 & -3.7 & -4.2 & +0.4 & -7.5 \\
\hline
\end{tabular}

\begin{tabular}{ccccccc}
\multicolumn{7}{c}{ PERCENTAGE CHANGE } \\
+34.3 & +4.4 & $+99.7^{2}$ & & +210.8 & $+68.8^{8}$ \\
-2.0 & -4.2 & +2.9 & -5.0 & +21.2 & +72.4 & +1.6 \\
+7.2 & +11.6 & +3.3 & +10.6 & +5.7 & +6.0 & -7.0
\end{tabular}

SOURCE: 15th Census of the United States, 1930, Agriculture, Vol. II; 14th Census of the United States, 1920, Agriculture, Vol. VI; U. S. Census of Agriculture, 1935, Vol. III.

${ }^{2}$ For 1909 and 1919 the figures relate to acreage in improved land, for 1924 and 1929 to crop acreage harrested, and for $193+$ to land used for crops (crop land harvested plus crop failures),

$=175,499$ acres.

${ }^{8} 1,000$ acres and over, 
a study (begun in 1929) of 148 farms in Kansas, shows calculated relative returns, at three prices for wheat, to operators on 200 acre horsepower and 500 acre tractorpower farms.

When wheat sells for $\$ 1.00$ a bushel, the highly mechanized large farm vields a net return for labor, management and capital more than double that of the smaller farm operating with animal power. When the price falls to 60 cents, the advantage of the mechanized farm decreases about one-half. A wheat price of 40 cents causes the mechanized farm to lose, whereas the non-mechanized farm has still a small gain. (Allowance must, of course, be made for differing capital investments.)

The advantages of mechanized farms are thus limited, while the disadvantages of non-mechanized farms are under certain conditions turned into relative advantages. This can retard the elimination of marginal producers for many years.

\section{d. Changes in farm organization}

The course of the wheat depression is determined by the length and nature of the process of adjustment, which in turn is decisively influenced by the manner in which marginal farmers are eliminated.

The concentration of crop land and the elimination of farms in the western states $^{\mathrm{u}}$ falls into two periods: the first from 1915 until about 1930, the second starting about the time of the onset of the industrial depression and still going on. Outstanding is the situation in Montana where the number of wheat farmers decreased from 35,000 to 14,000 between 1915-17 and 1929," a period of rapid expansion in acreage and production. This example cannot be generalized, but the tendency toward a concentration of farms can be observed in all districts where mechanization was important. The following evidence concerning all kinds of farms strongly supports the conclusion that concentration occurred in wheat farming, although there is no possibility of getting sufficient evidence of this tendency for wheat alone."

In the main wheat producing states, the crop land harvested by large farms showed with few exceptions the highest, and, in some cases, the only increase (Table 5), both from 1909 to 1919 and from 1924 to 1929. (The record of Nebraska from 1909 to 1919 was exceptional; acreage decreased in all size groups.) Comparisons be-

\footnotetext{
"The five winter wheat states (Kansas, Oklahoma, Texas, Colorado and Nebraska) and the four important spring wheat states (North Dakota, South Dakota, Montana and Washington) were chosen for analysis.

${ }^{2} Y$ earbook of Agriculture, 1932, p. 419: "Investigations made in Montana indicate that. where 35,000 wheat farmers were operating in 1915-17, there were only 14,000 in 1929 and they in turn were handling a larger acreage."
}

tween 1909-19 and 1924-29, and between 1919 and 1924, are difficult because of modifications in the Census definition of crop land harvested and of improved land. In general the tendency already marked in 1909-19 in these states has unquestionably persisted. The period 1924-29 is more significant since it indicates that the trend toward concentration is independent of the specific conditions created by the $W$ ar. Acreage increased in the wheat producing states between 1909 and 1919 in all size groups above 175 acres, the amount depending on differences in farm organization and farm crops as well as on soil and climatic conditions. The movement is related to the limited advance of mechanization during the War, in all states except Washington and Nebraska. The decrease in acreage in the 100-174 acre group is striking during both 1909-19 and 1924-29." Acreage expansion during 1924-29 was due chiefly to a concentration in size groups that were large enough for mechanized methods, or in which acreage could be increased to a point where mechanization became feasible. In most states the increase in crop land harvested on farms above 500 acres equals or surpasses the total increase. In some states, because of special conditions influencing the optimum size for mechanization, expansion occurred in the 260 acre group upwards; in others, as for example, Montana, Kansas, North Dakota, Washington, Colorado, the increase in the size groups above 500 acres far exceeded the total increase. The striking feature of this period was the rapid concentration of crop acreage harvested, partly because of the addition of smaller farms to larger ones, partly because of the plowing of virgin prairie and range lands, or of breaking new lands into new farms. The decrease in aggregate acreage of medium size farms was far greater than between 1909 and 1919. It was general in the 100-174 acre group; in most states, however, the 175-259 acre group also showed heavy decreases; acreage in the 260-499 acre group either decreased

${ }^{25}$ The sole source is the Census of Agriculture, which does not allow a separation of wheat farming. Its figures rather tend to understate the concentration, which was probably more pronounced in wheat farming than in farming as a whole. There are other difficulties involved in the comparison of these Census data: the census of 1930 was taken as of April 1 instead of January 1, as were the censuses of 1920 and 1925. This modification may affect the number of farms included in the three censuses, but there is reason to believe that, if so, the effect is much the same in all size groups (with the probable exception of the group 'less than 100 acres' which is of little interest in our analysis). The influences of climatic and specific economic conditions in the various Census years on the extent of crop acreage harvested cannot be separated. Despite all these difficulties the use of Census figures pertaining to changes in crop acreage and in the number of farms is warranted in order to illustrate the process of concentration of acreage and elimination of farms.

"In Montana and Colorado, where acreage expanded in all size groups, the increases are smallest in the 100-174 acre group. 
or the increases are negligible relatively to those in the larger size groups. ${ }^{15}$

Changes in the number of farms, ${ }^{20}$ by size groups, when changes in production methods were most rapid, should indicate which type of farm has been forced out $;^{17}$ and it may hint at the probable process of adjustment in agricultural production. Disregarding features due to specific conditions in individual states, we can observe a marked tendency during 1925-30 $:^{18}$ farms of more than 500 acres increased in number throughout the great wheat growing area (Table 6) except in Washington, where only farms above 1,000 acres increased. The decreases centered in the 100-499 acre groups. The resistance of the various medium size groups varied from period to period and from state to state, with the exception of the 100-174 acre group which decreased rapidly throughout. The general conclusion from an analysis of the two decades in which mechanization progressed rapidly, especially in the later period, is that farms that had the advantages of neither small nor large size were eliminated. The changes between 1930 and 1935 as revealed in the 1935 Census cannot as yet be adequately evaluated. They indicate, however, that recent developments, during the most severe part of the agricultural depression, are by no means clearcut. They do not indicate a continuation of the tendency toward concentration which was so pronounced before the industrial depression. If it turns out that the tendency toward concentration was checked, the probable explanation

${ }^{18}$ Data on changes in "land used for crops" between 1929 and 1934 are given in Table 5. On account of the severe drought of 1934, it was necessary to include 'crop failure' for 1934 ; i.e., 'crop land harvested' in 1929 was compared with 'crop land harvested' plus 'crop failure' in 1934. For 1929 'crop failure' was not given for the various size groups. This limits the comparability of the two sets of figures. Furthermore, the crop reduction program of the AAA had different effects on the extent of crop acreage in the various size groups in 1934. These are some of the reasons why we have not much confidence in a comparison of 1929 and 1934. Considering these limitations, we find strong indications that the trend of the period 1919-29 has not been continued. North Dakota, South Dakota and Montana show a decline in the large size groups not less or more than in the medium size groups. In Nebraska the decline is smaller in the size groups 500-999 and 1000-4999 than in the medium size groups, and a small increase occurred in the size group 5000 acres and over. In Kansas the large size groups seem to have continued their expansion. In Colorado the increase in the large size groups was smaller than in the medium and small sizes; the group of 5000 acres and over decreased.

${ }^{20}$ The farm is here treated as an organizational unit, not as an area of arable land.

"This means either that farms in such size groups could not survive or that they had to be enlarged (and thus fall in higher size groups) in order to exist.

${ }^{28} \mathrm{~A}$ generalization for the earlier periods is more difficult though the increases or relatively lower decreases occur in the larger size groups. will be that at the bottom of the depression mechanized farms no longer enjoyed cost advantages.

The shifts in farm organization and production in the fastern states are different from those in the Great Plains, Mountain and Pacific states. The limitations upon the application of large scale mechanized methods in these regions resulted mainly in a decrease in acreage during 1909-19 and 1924-29. It is hardly possible to determine to what degree mechanization in the West is responsible for the reduction in acreage and in the number of farms in the East. It undoubtedly played a great role, though the topographic and general farming conditions in the Easi had already caused decreases in crop acreage prior to 1910 . Before analyzing the process of elimination in the eastern states, it is worth pointing out that there is rarely a tendency to a concentration of crop acreage (Table 7 ). From 1909 to 1919 , when concentration was very great in the western states, crop acreage on farms of more than 500 acres decreased in approximately the same proportion as in the smaller size groups. From 1924 to 1929 , farms above 260 acres in the New England, Middle Atlantic and East North Central States increased in acreage; the smaller size groups decreased. In no division, however, can the absolute increases in crop acreage in these size groups be regarded as a significant tendency toward concentration, the percentage of acreage in the large size groups being negligible. ${ }^{20}$

In the East no uniform tendency is evident in the process of elimination (Table 8). Between 1910 and 1920 in New England and the Middle Atlantic States the number of farms decreased in all groups, less, however, in the medium size groups (175-499 acres) than in the larger size groups. Only the 100-174 and 175-259 acre groups in the East North Central States actually increased. The reason may be that cost-reducing mechanized methods in the East were best adapted to the medium size groups, owing to topographic, soil and climatic conditions, and to the prevailing type of farm organization. Between 1925 and 1930 in all three divisions the number of farms in the 100-175 acre group (in New England and the Middle Atlantic States even in the $175-259$ acre group) diminished, while the larger size groups increased only slightly. The development in the East was different from that in the West and does not indicate a definite trend in farming systems. ${ }^{\infty}$

${ }^{10}$ Table 7 contains also changes in crop acreage between 1929 and 1934. In all three sections acreage increased in all size gloups without exception, reversing the trend observed between 1909 and 1929. We do not believe that this means a definite change of the previous trend.

${ }^{30}$ It is proper to note that there have undoubtedly been variations in the degree of coverage of Census enumerations of farms, and that these variations have been greater in certain size groups than in others. John D. Black and R. H. Allen have discussed (footnote $e^{20}$ concluded on $p .14$ ) 
TABLE 6

Elimination of Farms, 1910-1935, in IMportant Wheat Producing States

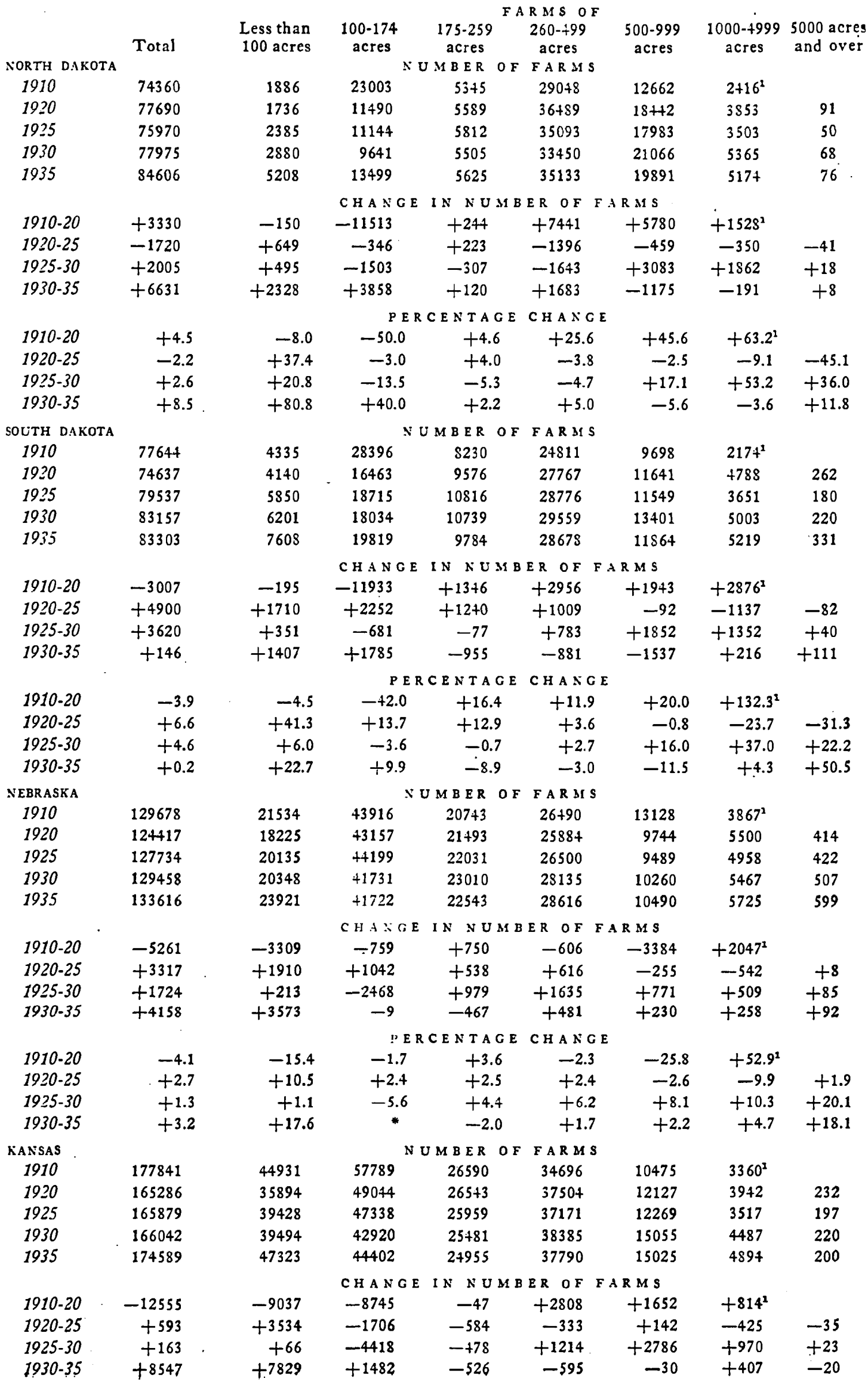


TABLE 6 (continued)

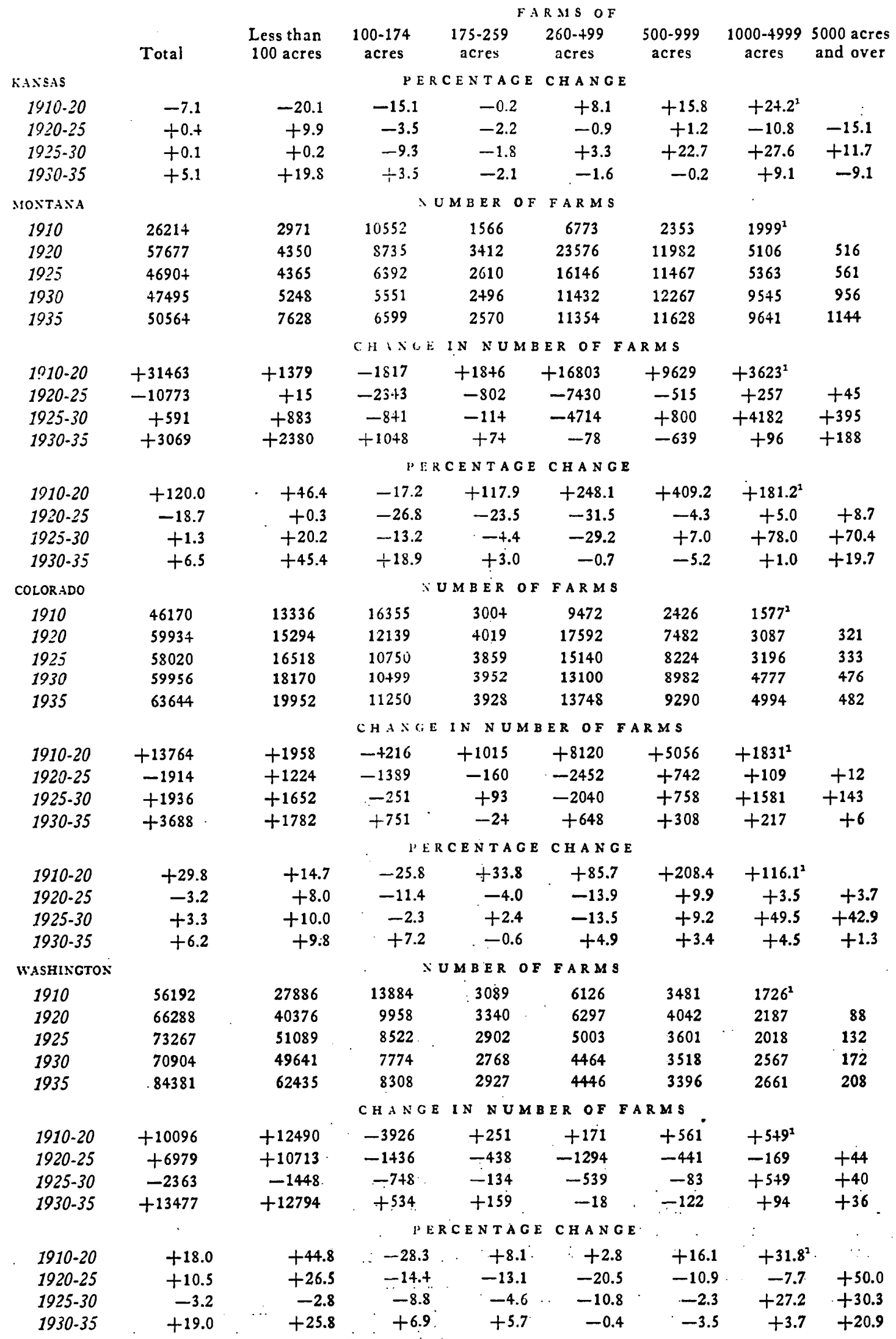

SOLRCE: 15th Census of the United States, 1930, Agriculture, Vol. II; 14th Census of the United States, 1920, Agriculture, Vol. VI; U. S. Census of Agriculture, 1935, Vol. III.

? 1,000 acres and over.

"Less than $1 / 10$ of 1 per cent. 


\section{e. Implications and probable future development}

The effects of elimination of farms and concentration of acreage on the future adjustment of production are rather complex. The process of elimination itself was by no means uniform even during 1924-29. The available statistics pertaining to the time of the deepest agricultural depression suggest that the situation has changed greatly since 1929. With a further price decline, the advantages of large scale mechanized farms became smaller and the losses incurred forced many of them out of production. Experience during this time indicates that a continuous increase in large scale mechanized farms, such as prevailed during 1919-29, meets difficulties that do not exist for big industry. These difficulties arise from peculiarities of agricultural production and marketing. Retarded concentration in agriculture must be partly attributed to the peculiar cost conditions in large scale farming. Large scale mechanization usually means specialization and very often a single crop. It is not certain that, even in the long run, the cost advantages of large scale operation can always counterbalance the ensuing risk. Moreover, in the period of rapid mechanization some areas were put under cultivation that in the long run are not suitable for arable farming. Consequently, part of the area that was cultivated during this period will have to be turned back to range. It is likely that an even greater part of this area cannot be used under the single crop system, for the fertility of the soil can be maintained only when crops are rotated. The droughts of 1934 and 1936 have shown how hazardous is cultivation on much of the sub-humid area in the Great Plains.

It is difficult to define with precision the future prospects of this area for wheat farming. The careful report of the National Resources Board ${ }^{21}$ emphasized as early as

(footnote ${ }^{20}$ concluded)

this matter, with particular reference to data for New England, in 'The Counting of Farms in the United States', Journal of the American Statistical Association, September 1937. They conclude that considerable acreage was omitted in 1924 and 1929, and included in 1934. The chief discrepancies occurred in the count of small farms, although the census for 1924 may have excluded a number of larger farms. These variations were not of equal importance in all parts of the country. "The number of farms involved in the changes in enumeration behavior from 1920 to 1935 was a considerable percentage of the total number only in the Northeastern states, in industrial counties scattered over the country, and in a few scattered areas such as the southern Appalachians, the cut-over regions of the Great Lake states and some sections of the Pacific states" (p. 459). It is to be noted that the analysis of changes in 'crop land harvested' would not be seriously affected by these variations, since the great bulk of harvested acreage is in farms of 260 acres or more.

wNational Resources Board, A Report on National Planning and Public Works in Relation to Natural Resources and Including Land Use and Water Resources, Part II, Report of the Land Planning Committee, November 1934, p. 132:
1934 that the western edge of the Great Plains was unfit for arable farming and that part of the wheat acreage in the western Dakotas, Nebraska, Kansas and Oklahoma must be turned to other uses. In addition, according to this report, between a million and a million and a half acres of inferior land will have to be abandoned and used for summer fallowing or livestock if the adjustments in farm organization necessary in these districts are made. Thus further development similar to that of the last two decades is limited. Even if adjustments improve the general aspect of wheat farming in these areas, large scale mechanization under such topographical and climatic conditions will involve a great risk.

Despite all these limitations, it appears certain that in the long run the mechanization of farming in the Great Plains will proceed, though the optimum type of organization may well be the mechanized family farm of a size somewhat smaller than that considered best in the decade after the War. The further development of farm machinery suitable for medium size farms and for more humid soil may alter the trend of the last two decades. The rapid mechanization since the $W_{a r}$ initiated changes in farm organization that have not as yet run their course. Undoubtedly mechanization will progress, and where the application of large machinery proves profitable a further concentration of acreage will take place. But the advantages that the perfecting of small scale machinery may bring will increase the resistance of medium size farms, so that even in the Great Plains area they may survive.

The rapid development of large scale mechanized methods in districts well suited to them has made possible the attainment of a new level of output. The cost advantage of highly mechanized farms until about 1931 resulted in notable changes in wheat farming, concentration of acreage and elimination of farms. But interruptions and reverses, largely due to the peculiar nature of costs in wheat farming, are likely to retard the adjustment process in the future.

\section{The Role of Mechanization in Cotton Farming}

One might expect technological progress to have an influence on the production of cotton similar to the effect on wheat production, but so far mechanization cannot be regarded as a major factor in the latest depression in cotton. In the future cotton production may be dominated by the application of mechanical devices and the consequences may resemble those experienced in the wheat depression. However, many serious impediments will retard mechanization of cotton production on a large scale. One of the most important is the tenure system in the Old Cotton Belt. The existence of this type of farming. is unfavorable to mechanization, which can be carried out only upon a 
TABLE 7

Concentration of Crop Land, 1909-1934, in Eastern States CHANGES IN CROP ACREAGE, ${ }^{1}$ CLASSIFIED ACCORDING TO SIZE OF FARMS IN WHICH ACREAGE WAS HELD

\begin{tabular}{|c|c|c|c|c|c|c|c|}
\hline & Total & $\begin{array}{l}\text { Less than } \\
100 \text { acres }\end{array}$ & $\begin{array}{c}100-17+ \\
\text { acres }\end{array}$ & $\begin{array}{c}\text { FARMS } \\
175-259 \\
\text { acres }\end{array}$ & $\begin{array}{l}\text { OF } \\
260-499 \\
\text { acres }\end{array}$ & $\begin{array}{c}500-999 \\
\text { acres }\end{array}$ & $\begin{array}{l}1000 \text { acre } \\
\text { and over }\end{array}$ \\
\hline NEW ENGLAND & \multicolumn{7}{|c|}{ ACREAGE (thousands of acres) } \\
\hline 1909 & 7255 & 2235 & 2198 & $2335^{2}$ & · & 313 & 175 \\
\hline 1919 & 6115 & $17+3$ & $18+t$ & $2107^{2}$ & & 294 & 128 \\
\hline 1927 & 4448 & $1+40$ & 1390 & 788 & 605 & 161 & 64 \\
\hline 1929 & 3659 & 991 & 1117 & 718 & 606 & 173 & 55 \\
\hline \multirow[t]{2}{*}{1937} & 4072 & 1242 & 1185 & 745 & 647 & 191 & 62 \\
\hline & \multicolumn{7}{|c|}{ CREAGE (thousands of acres) } \\
\hline $1909-19$ & -1140 & -492 & -354 & $-228^{2}$ & & -19 & -47 \\
\hline $1924-29$ & -789 & -449 & -273 & -70 & +1 & +12 & -9 \\
\hline \multirow[t]{2}{*}{$1929-34$} & +413 & +251 & +68 & +27 & +41 & +18 & +7 \\
\hline & \multicolumn{7}{|c|}{ PERCENTAGE CHANGE } \\
\hline $1909-19$ & -15.7 & -22.0 & -16.1 & $-9.8^{2}$ & & -6.1 & -26.9 \\
\hline $1924-29$ & -17.7 & -31.2 & -19.6 & -8.9 & +0.2 & +7.5 & -14.1 \\
\hline $1929-34$ & +11.3 & +25.3 & +6.1 & +3.8 & +6.8 & +10.4 & +12.7 \\
\hline
\end{tabular}

MIDDLE ATLANTIC

$\begin{array}{ll}1909 & 29321 \\ 1919 & 26562 \\ 1927 & 16482 \\ 1929 & 14324 \\ 1934 & 1514\end{array}$

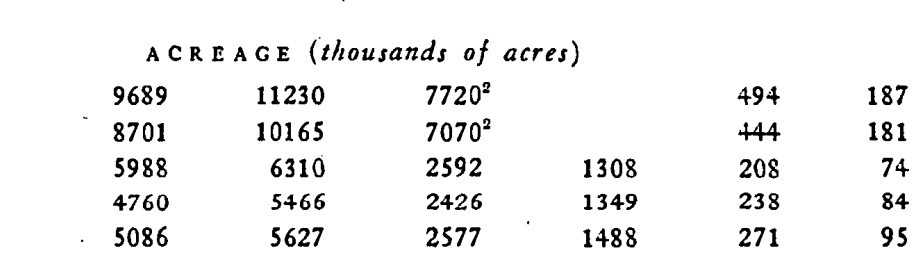

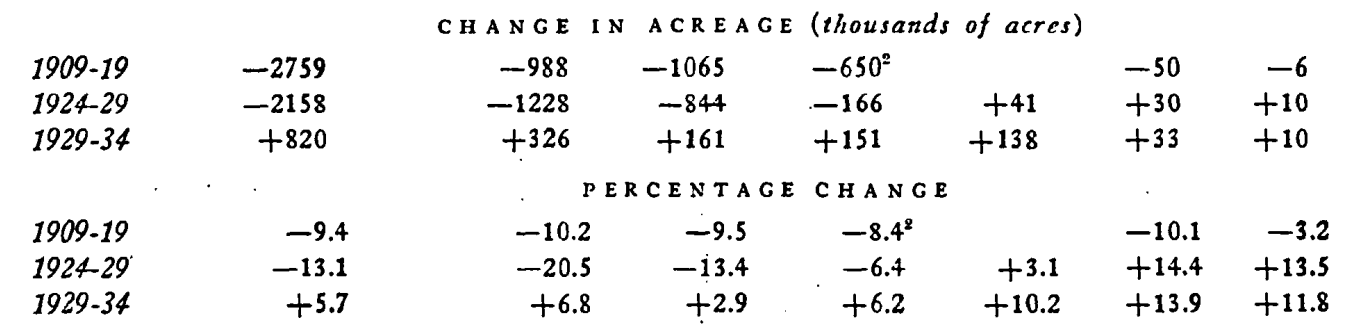

EAST NORTH CENTRAL

\begin{tabular}{|c|c|c|c|c|c|c|c|}
\hline \multirow[b]{2}{*}{1909} & \multicolumn{7}{|c|}{ ACREAGE (thousands of acres) } \\
\hline & 88947 & 26023 & 31821 & $28505^{2}$ & & 2027 & 570 \\
\hline 1919 & 87895 & 24854 & 32716 & $27953^{2}$ & & 1837 & 535 \\
\hline 1924 & 59114 & 15972 & 22200 & 11909 & 7631 & 1114 & 287 \\
\hline 1929 & 56644 & 13313 & 20937 & 12088 & 8617 & 1379 & 310 \\
\hline \multirow[t]{2}{*}{1934} & 59265 & 14542 & 21381 & 12369 & 9046 & 1556 & 370 \\
\hline & & CHANGE IN & ACREAGE & (thousands & of acres) & & \\
\hline $1909-19$ & -1052 & -1169 & +895 & $-552^{2}$ & & -190 & -35 \\
\hline $1924-29$ & -2470 & -2659 & -1263 & +179 & +986 & +265 & +23 \\
\hline \multirow[t]{2}{*}{$1929-34$} & +2621 & +1229 & +444 & +281 & +429 & +177 & +60 \\
\hline & \multicolumn{7}{|c|}{ PERCENTAGE CHANGE } \\
\hline $1909-19$ & -1.2 & -4.5 & +2.8 & $-1.9^{2}$ & & -9.4 & -6.1 \\
\hline $1924-29$ & -4.2 & -16.7 & -5.7 & +1.5 & +12.9 & +23.8 & +8.0 \\
\hline $1929-34$ & +4.6 & +9.2 & +2.1 & +2.3 & +5.0 & +12.8 & +19.4 \\
\hline
\end{tabular}

SOURCE: 15th Census of the United States, 1930, Agriculture, Vol. II; 1tth Census of the United States, 1920, Agriculture, Vol. VI; Abstract of the 14th Census, 1920, Agriculture; Statistical Abstract of the United States, 1919, 1929, 1931; U. S. Census of Agriculture, 1935, Vol. III.

'For 1909 and 1919 the figures relate to acreage in improved land, for 1924 and 1929 to crop land harvested, and for 1934 to land used for crops (crop land harvested plus crop failures).

$=175-499$ acres. 
much larger farm, in a technical sense, ${ }^{\text {, }}$ than that prevailing in this region. Another serious hindrance is the topography and climate of a wide area of the Cotton Belt. Large sections are hilly' and wooded. Farming is done in small fields of irregular shape, which makes the use of large machinery impossible. Because the humid climate in wide sections of the Old Cotton Belt is conducive to weed growth, much hand labor is required in cultivation.

In addition, technical factors have prevented the modernization of a very important part of the production process. Cotton picking, the process that requires most labor, is still done almost exclusively by hand. Even in those sections where. the social system and natural conditions do not impede extension of acreage and mechanization, the farming system cannot be changed until a mechanical cotton picker has been perfected. ${ }^{23}$ Hence production by large scale mechanized methods faces severe diffculties. Either labor is short at picking and hoeing time or else farms are burdened with a surplus of workers during the entire year, because picking and hoeing require a peak labor supply several times the minimum in the off season.

Comparison of farms reporting tractors in the Old Cotton Belt with those in leading wheat producing states shows that in 1930 about one farm in three used the tractor for producing wheat as against one in fifty for producing cotton.

During the decade 1920-30 the number of farms in the Cotton Belt using tractors increased, but remained under 4 per cent of the total even in North Carolina, ${ }^{24}$ the state reporting the largest number of tractors. The higher percentage of tractors on farms in Texas and Oklahoma is due mainly to wheat farms, which are highly mechanized in this region. For cotton production in certain districts of these states, however, the tractor is used more extensively than in the Old Cotton Belt.

The above figures suggest that the farming system in the Old Cotton Belt has not as yet been materially affected by mechanization. The problems similar to those growing out of the mechanization of wheat farming do not yet face cotton farmers.

The rapid expansion of acreage and production in parts of Texas and Oklahoma, where conditions are fairly favorable to mechanization, seems to contradict this statement.

\footnotetext{
${ }^{20} \mathrm{Ownership}$ is not the decisive point, for we are considering only changes in productive methods and their effects. This justifies for our purpose the use of Census figures, which are based on the technical unit rather than the unit of proprietorship, croppers and tenants being counted as farmers.

Despite great progress, the experimental pickers do not give promise of wide use in the near future.

${ }^{24}$ Several farms under common ownership are counted separately; cf. footnote 22 .
}

In order to determine the influence of mechanization on the expansion of production in these areas we compare their situation with that of other states where production was similarly expanded.

The acreage figures in themselves are surprising. The sharp increase in Texas and Oklahoma occurred during 1919-24, with a 53 per cent aqdvance in Texas and one of 47 per cent in Oklahoma. During 1924-29, however, when mechanization in wheat production and wheat acreage in the Great Plains states rose most notably, cotton acreage increased only 8 per cent in Oklahoma, and decreased 1 per cent in Texas. At the same time, acreage in some states of the Old Cotton Belt rose much more: in Louisiana 35.5, and in Mississippi 34.6 per cent. This may indicate that the acreage expansion in Texas and Oklahoma between 1919 and 1924 was not so much a result of the introduction of mechanized methods as of favorable cotton prices (especially in comparison with cattle prices). This favorable condition followed a reduction of acreage and production, particularly in Georgia and South Carolina, on account of the boll-weevil damage. It is a notable fact, however, that acreage increases in Texas and Oklahoma during 1919-24 (7,100,000 acres) were more than double the acreage decreases in Georgia and South Carolina $(2,650,000$ acres $)$. On the other hand, if the expansion of acreage in 1919-24 was due to mechanization, it is difficult to understand why mechanization was not carried further, as it was in wheat. If mechanization is advantageous-and the price situation was not unfavorable for mechanized farms-we would expect it to progress; we would also expect that acreage would expand further in the following period, unless the total figures mean that acreage expansion in counties suited to mechanized methods was approximately counterbalanced by decreases unsuited to mechanization.

It is therefore not sufficient to analyze cotton production by states. In order to gauge the role of technical progress we must analyze production in those counties which expanded their acreage substantially and in others where acreage harvested declined for reasons other than crop failures.

The principal questions to be raised in respect of mechanization in cotton farming are: (1) Did mechanization play a determining role in the expansion of açreage and production of cotton? (2). If there were shifts in size groups and consequently in the farming system, were they caused by mechanization?

Texas and Oklahoma on the one hand, and Mississippi on the other, may be regarded as representative. We have selected for our analysis in these three states the counties showing sharp increases or decreases of cotton acreage in both periods, 1919-24 and 1924-29, or an increase in the 
TABLE 8

Elimination of FakMS, 1910-1935, in EASTERN States

\begin{tabular}{|c|c|c|c|c|c|c|c|}
\hline & & & & FAR M & $S \quad O F$ & & \\
\hline & Total & $\begin{array}{l}\text { Less than } \\
100 \text { acres }\end{array}$ & $\begin{array}{c}100-17 t \\
\text { acres }\end{array}$ & $\begin{array}{c}175-259 \\
\text { acres }\end{array}$ & $\begin{array}{c}260-499 \\
\text { acres }\end{array}$ & $\begin{array}{c}500-999 \\
\text { acres }\end{array}$ & $\begin{array}{l}1000 \text { acres } \\
\text { and over }\end{array}$ \\
\hline NEW ENGLA & & & & & & & \\
\hline & & & UM BER & OF FARM & & & \\
\hline 1910 & $1 S \$ 802$ & 114058 & +4019 & 17972 & 10036 & 2139 & 578 \\
\hline 1920 & 156564 & 91039 & 37993 & 16172 & 9001 & 1916 & $+1 \mathfrak{3}$ \\
\hline 1925 & $159+89$ & 98024 & 36799 & 14634 & 8110 & 1544 & 378 \\
\hline 1930 & $12+925$ & 70001 & 30656 & 13774 & 8329 & 1773 & 392 \\
\hline 1935 & $15 S 2+1$ & 101148 & 32075 & 14066 & 8674 & 1854 & $42+$ \\
\hline & & $\mathrm{CHANG}$ & $E I N N U$ & M B ER OF & ARMS & & \\
\hline $1910-20$ & -32238 & $-23019^{\circ}$ & -6026 & -1800 & -1035 & -223 & -135 \\
\hline $1920-25$ & +2925 & +6985 & -1194 & -1538 & -891 & -372 & -65 \\
\hline $1925-30$ & $-3+56+$ & -28023 & -6143 & -860 & +219 & +229 & +14 \\
\hline 1930.35 & +33316 & +31147 & +1419 & +292 & +345 & +81 & +32 \\
\hline & & & RCENTAC & CE C HANC & & & \\
\hline $1910-20$ & -17.1 & -20.2 & -13.7 & -10.0 & -10.3 & -10.4 & -23.4 \\
\hline $1920-25$ & +1.9 & +7.7 & -3.1 & -9.5 & -9.9 & -19.4 & -14.7 \\
\hline $1925-30$ & -21.7 & -28.6 & -16.7 & -5.9 & +2.7 & $+1+.8$ & +3.7 \\
\hline $1930-35$ & +26.7 & +44.5 & +4.6 & +2.1 & +4.1 & ++.6 & +8.2 \\
\hline AIIDDLE ATL & & & & & & & \\
\hline & & & U M BER & OF FARMS & & & \\
\hline 1910 & +68379 & 289996 & 123756 & 37656 & 14654 & $18+8$ & 469 \\
\hline 1920 & $+251+7$ & $2565+0$ & 116009 & 36009 & 14428 & 1736 & 425 \\
\hline 1925 & +15868 & 263408 & 108546 & 32548 & 12665 & $1+13$ & 288 \\
\hline 1930 & 357603 & 210861 & 98813 & 32186 & 13744 & 1666 & 333 \\
\hline 1935 & $39768+$ & 248399 & 100066 & 32884 & 14256 & 1722 & 357 \\
\hline & & CHANC & $E I N N U$ & M BER OF & FAR M S & & \\
\hline $1910-20$ & -+3232 & -33456 & -7747 & -1647 & -226 & -112 & -44 \\
\hline $1920-25$ & -6279 & +6868 & -7463 & -3461 & -1763 & -323 & -137 \\
\hline $1925-30$ & -61265 & -52547 & -9733 & -362 & +1079 & $+25 \hat{3}$ & +45 \\
\hline $1930-35$ & ++0081 & +37538 & +1253 & +698 & +512 & +56 & +24 \\
\hline & & & C ENTAC & $\mathrm{SECHANG}$ & & & \\
\hline $1910-20$ & -9.2 & -11.5 & -6.3 & -4.4 & -1.5 & -6.1 & -9.4 \\
\hline $1920-25$ & -1.5 & +2.7 & -6.4 & -9.6 & -12.2 & -18.6 & -32.2 \\
\hline $1925-30$ & -14.6 & -19.9 & -9.0 & -1.1 & +8.5 & +17.9 & +15.6 \\
\hline $1930-35$ & +11.2 & +17.8 & +1.3 & +2.2 & +3.7 & +3.4 & +7.2 \\
\hline
\end{tabular}

EAST NORTH CENTRAL

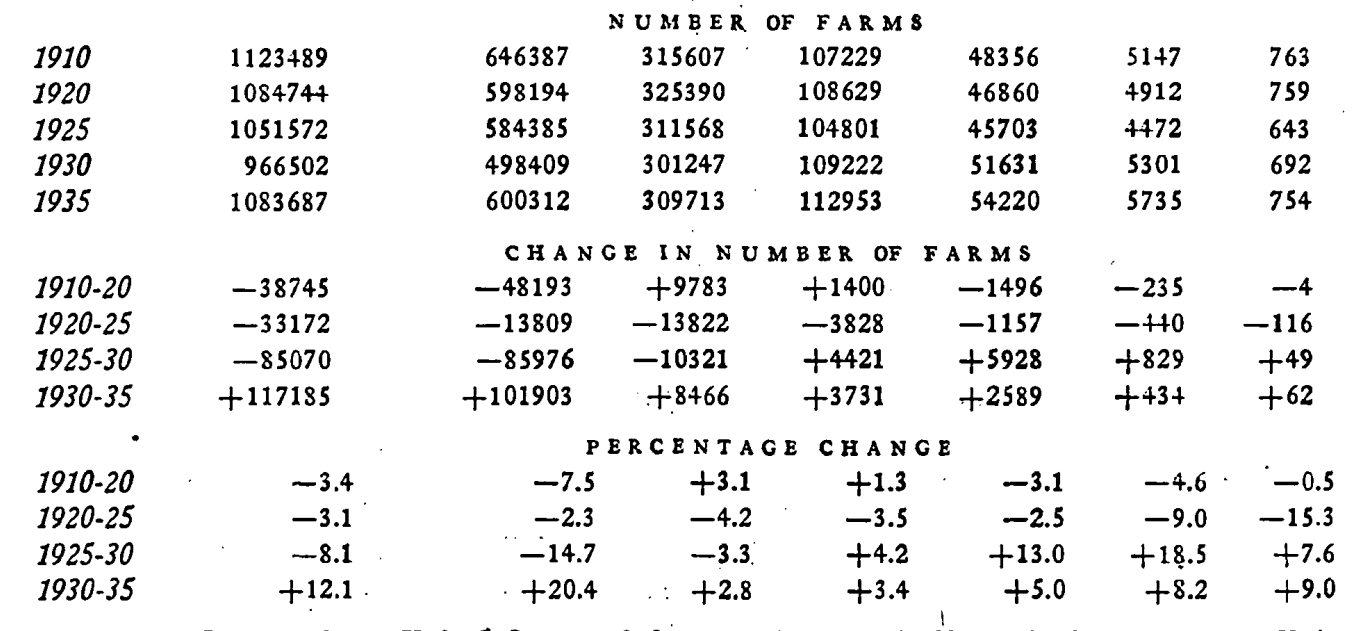

SOURCE: 15th Census of the United States, 1930, Agriculture, Vol. II; 14th Census of the United States, 1920, Agriculture, Vol. VI; Statistical Abstract of the United States, 1924; U. S. Census of Agriculture, 1935, Vol. III. 
TABLE 9

Farms Reporting 'Tractors in Leading Cotton AND IVheat Producing States

$$
1920
$$

1925

1930

(percentage of all farms)

\begin{tabular}{lccc} 
Wheat Producing Statis & \multicolumn{3}{c}{ (pcrcentage of all farms) } \\
North Dakota & 15.2 & 20.9 & 43.8 \\
South Dakota & 16.3 & 20.6 & 37.2 \\
Montana & 11.9 & 12.5 & 36.0 \\
Kansas & 9.8 & 17.2 & 35.6 \\
Wheat and Cotton Producing States & & & \\
Oklahoma & 3.0 & 5.0 & 11.4 \\
Texas & 1.9 & 3.2 & 6.4 \\
Cotton Producing States & & & \\
North Carolina & 0.8 & 2.7 & 3.9 \\
Tennessee & 0.7 & 1.8 & 2.7 \\
Louisiana & 1.6 & 1.9 & 2.4 \\
Georgia & 0.7 & 1.5 & 2.1 \\
South Carolina & 0.6 & 1.5 & 2.0 \\
Arkansas & 0.6 & 1.2 & 1.8 \\
Alabama & 0.3 & 1.0 & 1.7 \\
Mississippi & 0.2 & 0.7 & 1.5
\end{tabular}

first period and a decrease in the second. We have chosen only those counties in which a major fraction of the acreage was planted in cotton. This selection facilitates the analysis since the data are not disturbed by the influence of other farm products. In most of the counties studied the percentage of crop land harvested which is in cotton farms is over 90. Thus the results become fairly conclusive. The analysis was restricted to a few features characteristic of productive methods and farm organization. An attempt was made to determine in what size brackets and under what technical conditions cotton acreage increased. Besides breaking the acreage down by size of farm ${ }^{25}$ Table 11 shows the total number of cotton farms and of those over 175 acres, to bring into prominence the number of farms that are assumed to be technically in a position to mechanize production. As a measure of the degree of mechanization, the number of farms reporting tractors in each county is given. In estimating the number of cotton farms using tractors we determined the percentage relation of the value of implements and machinery on cotton farms to the total value of such implements and machinery on all farms in each county studied. The total number of farms reporting tractors in each county was then multiplied by this percentage, to yield the estimates in Table 10.

Table 11 contains three groups of counties divided according to the apparent causes of increase in production. The first group is composed of counties that have large farms in which a definite influence of mechanization on the expansion of acreage can be assumed. The second group contains counties in areas where topographic and climatic conditions make large acreage and mechanization possible

${ }^{25}$ The division into size groups is available only for 1924-29. As will be shown, this limitation does not seriously impede the analysis as the data for this period are sufficient to clarify the point in question. but where, despite the existence of large farms, the increase in cotton acreage is obviously not due to mechanization. In the third group the increases are more or less independent of mechanization and size of farms, the expansion in acreage having largely occurred on farms that are technically not in a position to apply mechanized methods.

- The first group is particularly significant because of the possibility of mechanization rather than because of any role it plays at present. Nueces, San Patricio, Tillman, Washita and Jackson counties prove that under certain conditions the cultivation of large cotton acreage with the use of mechanized methods has advantages, although cotton picking requires a large amount of human labor. This group has as yet slight importance; its output constitutes only a small percentage of total cotton production and acreage increases in mechanized cotton farms in this group have played only a minor role in the total increases. Expansion of acreage and production thus took place in counties where new as well as old methods were used. Mechanization in cotton played but a minor role as compared to its influence on the expansion of wheat acreage. Further, the expansion in acreage of mechanized cotton farms did not cause a reduction of acreage in small farms.

The second group of counties is most characteristic of production methods and the development of cotton acreage in the new cotton areas of southwestern Oklahoma and Texas. Many cotton experts stress the fact that those areas where cotton production in larger tracts is possible, independent of the use of the tractor, have cost advantages over districts where the social and topographical conditions compel cotton farming in small tracts. ${ }^{\infty}$ We cannot tell as yet whether these cost advantages over the older sections of the Cotton Belt can be maintained in the long run. It seems, however, that despite climatic hazards, these new districts will expand acreage. According to Department of Agriculture estimates, cotton acreage in the sub-humid

${ }^{20}$ One may, of course, consider the use of larger equipment (without the use of tractors) as a form of mechanization.

TABLE 10

Cotton ACREAGe HaRvested in the Most Important Cotton Producing States, 1919-1929 (thousands of acres)

$\begin{array}{lrrrrr} & 1919 & 1924 & 1929 & 1919-24 & 1924-29 \\ \text { Texas } & 11,165 & 17,049 & 16,875 & +52.7 & -1.0 \\ \text { Oklahoma } & 2,587 & 3,803 & 4,114 & +47.0 & +8.2 \\ \text { Mississippi } & 2,854 & 2,999 & 4,037 & +5.1 & +34.6 \\ \text { Alabama } & 2,556 & 2,939 & 3,555 & +15.0 & +21.0 \\ \text { Arkansas } & 2,489 & 2,768 & 3,451 & +11.2 & +24.7 \\ \text { Georgia } & 4,776 & 2,677 & 3,378 & -43.9 & +26.2 \\ \text { South Carolina } & 2,599 & 2,047 & 1,974 & -21.2 & -3.6 \\ \text { Louisiana } & 1,304 & 1,427 & 1,934 & +9.4 & +35.5 \\ \text { North Carolina } & 1,349 & 1,732 & 1,635 & +28.4 & -5.6 \\ \text { Tennessee } & 761 & 930 & 1,045 & +22.2 & +12.4\end{array}$
SOURCE: The World Cotton Situation, Part II; U. S. Department of Agriculture, February 1936, p. 69. 
TABLE 11

Cotton Production and Production Methods in Typical Cotton Counties of Öhlahoma and Texas, 1919-1929

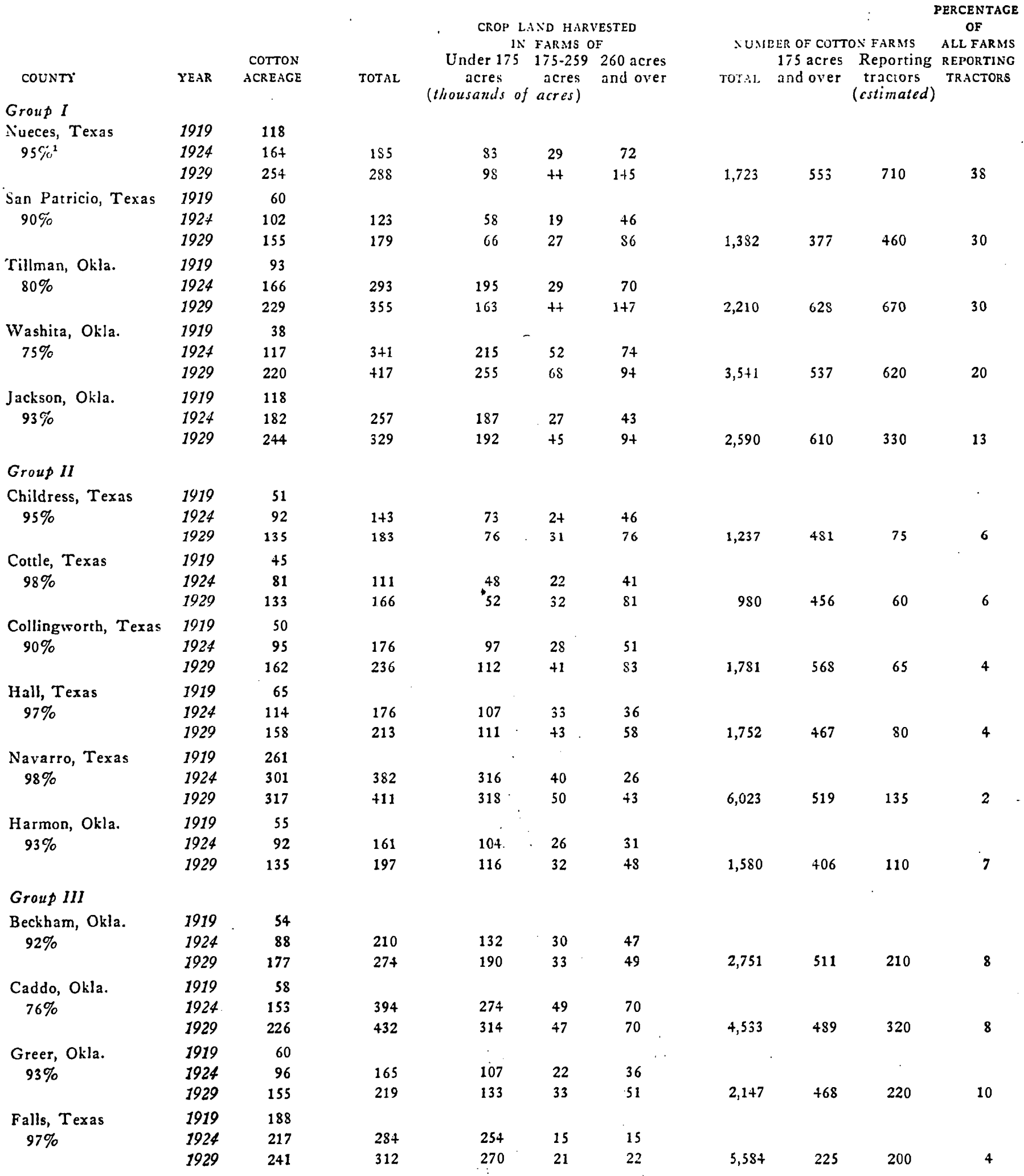

SOURCE: 15 th Census of the United States, 1930, Agriculture, Vol. II and III.

${ }^{2}$ The figure below each county name indicates the percentage relation of acreage harvested in cotton farms in 1929 to total acreage in all farms. 
sections of Texas and Oklahoma suitable for extensive methods constituted about 20 per cent of total cotton acreage in the United States during 1925-29. ${ }^{27}$ Production in this area was about 16 per cent of total American cotton production. Natural conditions in this area lend themselves to extensive cotton production without tractors. Department of Agriculture investigations show that the most common work unit in the new cotton districts is 2-row equipment with a 4 to 6 horse team. In the other districts the unit is one man and one horse with $1 / 2$ row equipment. The differences are largely a result of differences in climatic conditions and in topography. This explains the fact that in many counties of southwestern Texas and Oklahoma more and more cotton has been produced on large farms without tractors. According to all indications the bulk of the increase in acreage, particularly between 1924 and 1929, was on larger farms that took advantage of topography and climate without using motive power.

The statistics referring to such counties as Childress, Cottle, Collingsworth, Hall, Navarro, Harmon (Group II) show that only a small percentage of farms use tractors, though cotton acreage in large farms rose rapidly. In the group of farms of 175 acres or more there were, in Collingsworth county, only 65 tractor farms in a total of 568 ; in Childress county there were only 75 tractor farms in a total of 481 . These relations show the situation clearly. Moreover, it is to be noted that increases in the ${ }^{\pi} U$. S. Department of Agriculture, The World Cotton Situation, Part II, p .22. acreage of the larger farms were not accompanied by a reduction in acreage of the smaller farms, as in wheat. Instead, there are many counties in the same area (Group III) where, despite the existence of mechanized or large farms, the bulk of the acreage increases occurred in the smaller size groups (for example, in Beckham, Caddo, Greer and Falls).

The sharpest contrast to the situation in wheat is found in those states in which production was increased notably in the small size groups, with no concentration of ownership. The conditions in Mississippi are typical. Table 12 shows the situation in several counties. It is significant that acreage in the group of farms under 100 acres increased much more rapidly between 1924 and 1929 than during the preceding five years. The situation in these counties is so obvious that the table can be simplified by giving merely the cotton acreage harvested, the percentage of 'tractorized' farms, total crop land harvested and crop land harvested in farms of more than 100 acres. In no case did the development in the larger size groups determine the total cotton acreage harvested.

The preceding analysis has a definite bearing on some questions that are of importance in relation to the role of mechanization in cotton farming. The necessity of selecting typical counties makes it impossible for us to get evidence on the extent of mechanization in total cotton production. But the fact that in districts suited for highly mechanized methods the use of the tractor is by no means general indicates that mechanization even there is still in

TAB LE 12

Production Methods in Typical Mississippi Counties, 1919-1929

\begin{tabular}{|c|c|c|c|c|c|c|c|c|c|c|}
\hline \multirow{4}{*}{$\begin{array}{l}\text { COUNTY } \\
\text { Bolivar }\end{array}$} & \multirow{4}{*}{$\begin{array}{l}\text { YEAR } \\
1919 \\
1924\end{array}$} & \multirow[b]{2}{*}{$\begin{array}{l}\text { COTTON } \\
\text { ACREACE } \\
\text { (thousand } \\
\text { acres) }\end{array}$} & \multirow{2}{*}{$\begin{array}{l}\text { PERCENTAGE } \\
\text { OF ALL FARMS } \\
\text { REPORTING } \\
\text { TRACTORS }\end{array}$} & & \multicolumn{4}{|c|}{ ALL LAND IN FARMS } & \multirow[b]{2}{*}{$\begin{array}{l}500 \text { acres } \\
\text { and over }\end{array}$} \\
\hline & & & & \multicolumn{2}{|c|}{$\begin{array}{l}\text { farms and over } \\
\text { (thousand acres) }\end{array}$} & \multicolumn{4}{|c|}{$\begin{array}{l}\text { acres } \\
\text { (thousand acres) }\end{array}$} & \\
\hline & & 216 & & & & 233 & 22 & 9 & 20 & 35 \\
\hline & & 224 & & 265 & 27 & 231 & 18 & 11 & 36 & 42 \\
\hline & 1929 & 287 & 1.2 & 331 & 30 & 286 & 28 & 13 & 30 & 43 \\
\hline \multirow[t]{3}{*}{ Lee } & 1919 & 41 & & & & 82 & 71 & 53 & 27 & 4 \\
\hline & 1924 & 53 & & 103 & 12 & 86 & 61 & 39 & 16 & 4 \\
\hline & 1929 & 72 & 0.9 & 120 & 12 & 102 & 67 & 40 & 25 & 1 \\
\hline \multirow[t]{3}{*}{ Leflore } & 1919 & 109 & & & & 126 & 16 & 6 & 20 & 41 \\
\hline & 1924 & 125 & & 158 & 10 & 143 & 16 & 8 & 17 & 41 \\
\hline & 1929 & 172 & 1.2 & 217 & 15 & 193 & 17 & 6 & 20 & 42 \\
\hline \multirow[t]{3}{*}{ Quitman } & 1919 & 71 & & & & 84 & 8 & $5:$ & 5 & 22 \\
\hline & 1924 & 66 & & 84 & 10 & 69 & 10 & 8 & 16 & 51 \\
\hline & 1929 & 100 & 0.9 & 116 & 10 & 106 & 14 & $11:$ & $1+$ & 26 \\
\hline \multirow[t]{3}{*}{ Sunflower } & 1919 & 152 & & & & 184 & 15 & $8 \therefore$ & 15 & 36 \\
\hline & 1924 & 192 & & 222 & 34 & 193 & 15 & 6 & 23 & 40 \\
\hline & 1929 & 286 & 0.9 & 329 & 27 & 281 & 25 & 8 & 18 & 46 \\
\hline
\end{tabular}

SOURCE: 15 th Census of the United States, 1930, Agriculture, Vol. II and III. 
its beginning. This becomes more evident if we observe the effect of mechanization on the various types of cotton farm, both in this area and in the Old Cotton Belt.

In contrast to wheat, small cotton farmers were not eliminated to any great extent, even in those counties where conditions are favorable to mechanization and larger acreage. In districts where the expansion of acreage in the decade 1919-29 occurred without mechanized methods no tendency towards concentration of farms appears. Acreage in small farms increased much more than in larger farms (above 100 acres). In the new wheat areas, however, the medium size farms, which correspond to the smaller size groups in the Cotton Belt, were in large degree eliminated. The figures showing a relative stability of the small size groups do not, of course, indicate the prosperity of this type of cotton farmer.

These observations refer only to the period here analyzed. Technical progress may hasten expansion of acreage in the new cotton districts and result in severe dislocations. in the farming system of the Old Cotton Belt. The mere fact that a tendency toward increasing acreage and production in the newer cotton areas can be observed indicates the direction of possible further shifts in cotton production in the United States. But so far, the increase in acreage in larger cotton farms does not seem to have greatly affected the adjustment process in cotton farming. Even if we assume that the analysis understated the importance of areas in which mechanization and large scale cotton farming took place, it is certain that the samples chosen should have shown the effect of a process of concentration on the various types of cotton farm. Mechanization, with increasing production, in larger farms has not as yet resulted in dislocations either in the areas in which it took place or in areas that continued to grow cotton in small tracts. Thus, the depression in cotton cannot be explained by mechanization and its consequences.

\section{PRODCCTION IN THE UNITED STATES}

Production of cotton was not expanded in the United States during the World War. Average production during the five years $1915-19$ was 20 per cent lower than in $1910-14$ ( $11,466,000$ as against $14,254,000$ bales). Owing chiefly to boll-weevil damage, particularly during 1920-23, average annual production in 1920-24 declined another 4 per cent, with a low record of 7,945,000 bales in 1921 .

During the general price decline of 1920-21 the price of cotton fell from a peak of 42 cents per pound in April 1920 to 12 cents in March 1921. The small crops of the boll-weevil years changed the price situation rapidly, raising the price of cotton fairly continuously to 36 cents per pound in December 1923. ${ }^{23}$ The favorable price may

${ }^{28}$ This, however, was not the only cause; improved business conditions also played a part. be regarded as the main incentive for expanding acreage and production in the following years, particularly in those districts of Texas and Oklahoma that remained unaffected by the weevil. The volume of 1914 production was not regained until 1925, when a crop of $16,105,000$ bales was harvested as against $16,112,000$ in 1914 . The high average yield of 192.8 pounds per acre in 1926 (1921: 132.5) resulted in a crop of $17,978,000$ bales. Boll-weevil damage and the triumph over it determined in large degree the course of cotton acreage and production during and after the War. In contrast to wheat the level of production did not rise (Chart 5).

$$
\text { CHART } 5
$$

COTTON ACREAGE AND PRODUCTION UNITED STATES

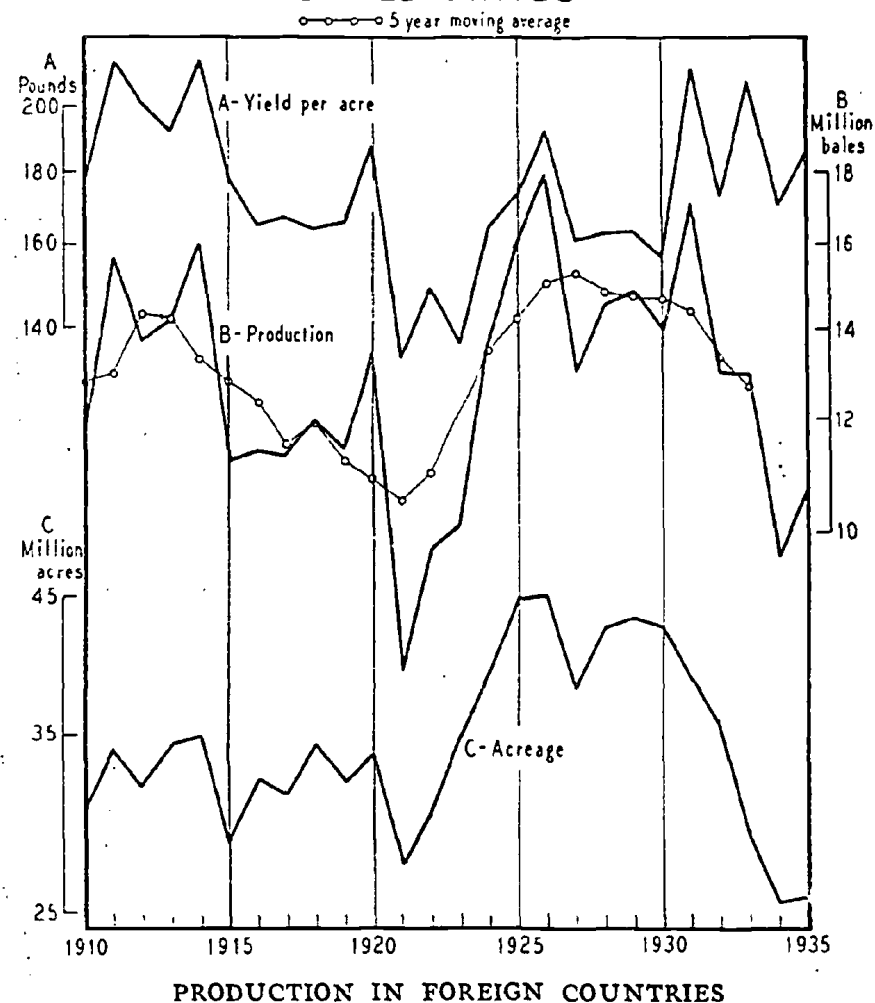

In foreign countries also cotton production decreased during the War, total production (excluding China) averaging 6.6 million bales in $1915-19$ as against 7.3 million bales in 1910-14. The 1914 level was not regained until 1924. As in America, the deficient years 1920 and 1921. and the favorable cotton price led to expansion in the following years. Between $1921^{\circ}$ and 1925 foreign cotton production (including China) rose from 7.5 to $11.8 \mathrm{mil}$ lion bales; average foreign production in 1925-20 exceeded pre-War production $(1910-14)$ by 29 per cent (Chart 6).

The post-War level of world cotton production did not, except in 1925, 1926 and 1931, exceed 1914 production. ${ }^{*}$ ${ }^{29}$ The movement of world cotton production, including China, is shown in Chart 6. 


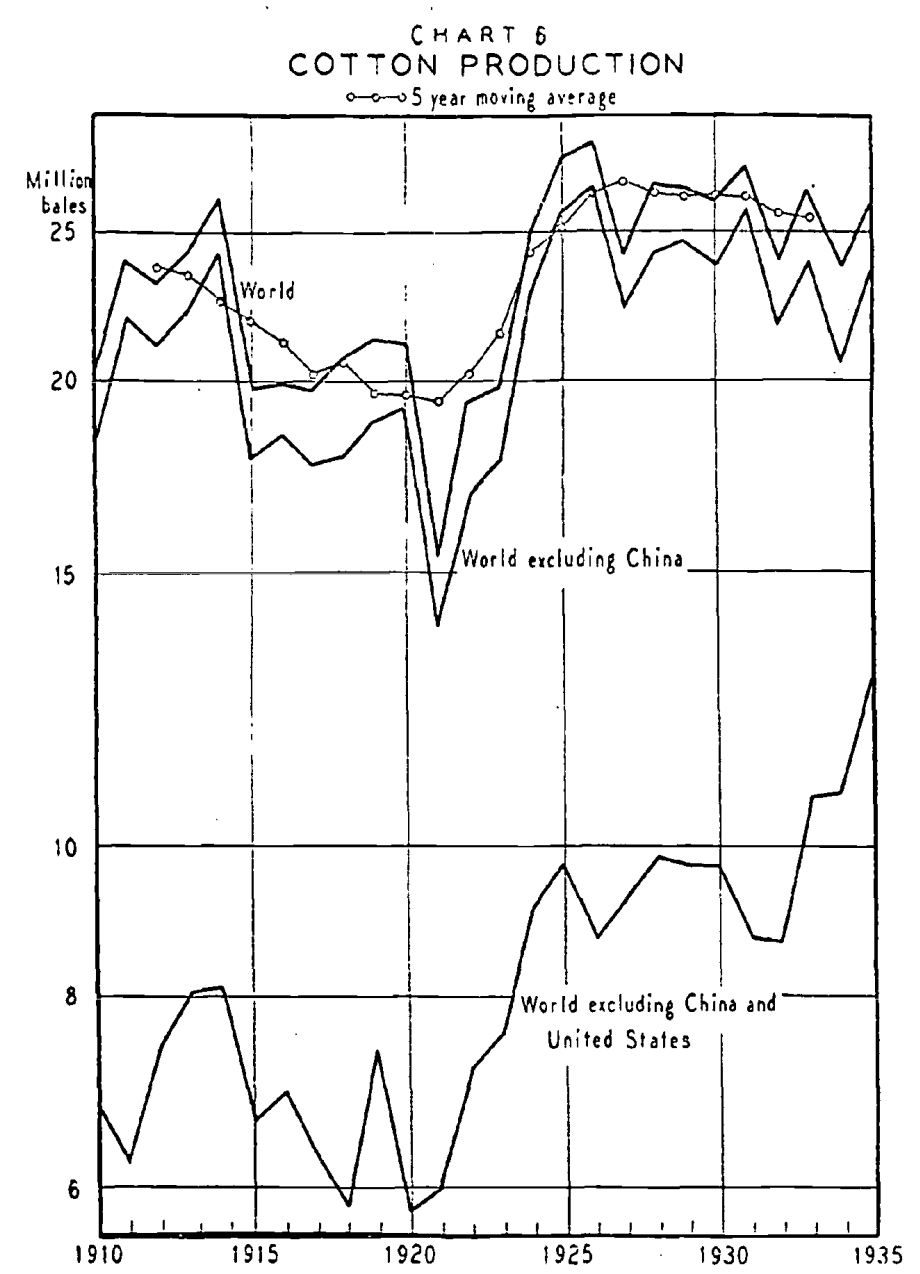

The difference between wheat and cotton production is fundamental : in foreign countries even more than in the United States cotton is grown almost exclusively on small farms that do not use mechanized methods. ${ }^{30}$ This fact influences the possibility of adjusting production to market conditions. Rapid expansion is somewhat limited, while reductions in

${ }^{30}$ The distribution according to size of farms in Egypt illustrates the organization of cotton farms outside the United States. The small size of the farming unit abroad is even more clearly revealed if we compare it with the size of farms in the wheat districts of the United States and Canada.

Landowners and Distribution of Land by Size of Holding, EGYPT, 1931

\begin{tabular}{|c|c|c|c|c|c|}
\hline \multirow{4}{*}{$\begin{array}{c}\text { SIZE OF } \\
\text { HOLDING } \\
\text { (acres) }\end{array}$} & \multirow{2}{*}{\multicolumn{2}{|c|}{ OWNERS }} & \multirow{2}{*}{\multicolumn{2}{|c|}{ AREA }} & AVERAGE \\
\hline & & & & & HOLDING \\
\hline & & Per & & Per & PER OWNER \\
\hline & Number & cent & Acres & cent & (acres) \\
\hline Less than 1 & $1,529,644$ & 68.2 & 605,707 & 10.1 & 0.4 \\
\hline $1-5$ & 554,550 & 24.7 & $1,218,521$ & 20.3 & 2.2 \\
\hline $5.1-10$ & 84,351 & 3.8 & 593,049 & 9.9 & 7.0 \\
\hline $10.1-21$ & 40,377 & 1.8 & 529,535 & 8.8 & 13.1 \\
\hline $21.1-31$ & •12,093 & 0.5 & 303,480 & 5.0 & 25.1 \\
\hline $31.1-52$ & 9,404 & 0.4 & 374,810 & 6.2 & 39.9 \\
\hline Over 52 & 12,708 & 0.6 & $2,390,418$ & 39.7 & 188.1 \\
\hline Total & $2,243,127$ & 100.0 & $6,015,521$ & 100.0 & 2.7 \\
\hline
\end{tabular}

Cf. P. K. Norris, Cotton Production in Egypt, U. S. Department of Agriculture, Technical Bull. 451, October. 1934. acreage and production (if necessary) are being and can be made more easily than in wheat, particularly in the West where no alternative crop is prevalent.

\section{The Role of Other Factors in the Agricultural Depression}

A. OTHER FACTORS IN THE WHEAT DEPRESSION

We have found that mechanization, by greatly influencing the supply of wheat, determined to a great extent the process of adjustment and therefore the course of the wheat depression. The impact of mechanization and its economic consequences were so heavy that to them may be attributed in large measure the long depression in wheat farming. It is, how'ever, difficult to illustrate adequately the situation in wheat by statistical series indicating the prosperity of wheat farmers. The nearest approximation appears to be the movement of the aggregate farm value of wheat, deflated by prices farmers paid. The statistical inadequacies of this series allow only a limited use of it, but its movement seems to confirm the expectations derived from the analysis of the adjustment process in wheat farming, namely that wheat farming must have been depressed throughout the pnst-TVar period, except for an improvement during 1924-27. If we use as a standard the income level of 1910-14, the series indicates that this level was exceeded only between 1924 and 1927, and that from 1920 on, except in these years, income was lower than before the War (Chart 7).

\section{CHART ?}

AGGREGATE FARM VALUE OF WHEAT (defiated by 'prices paid by farmers' index)

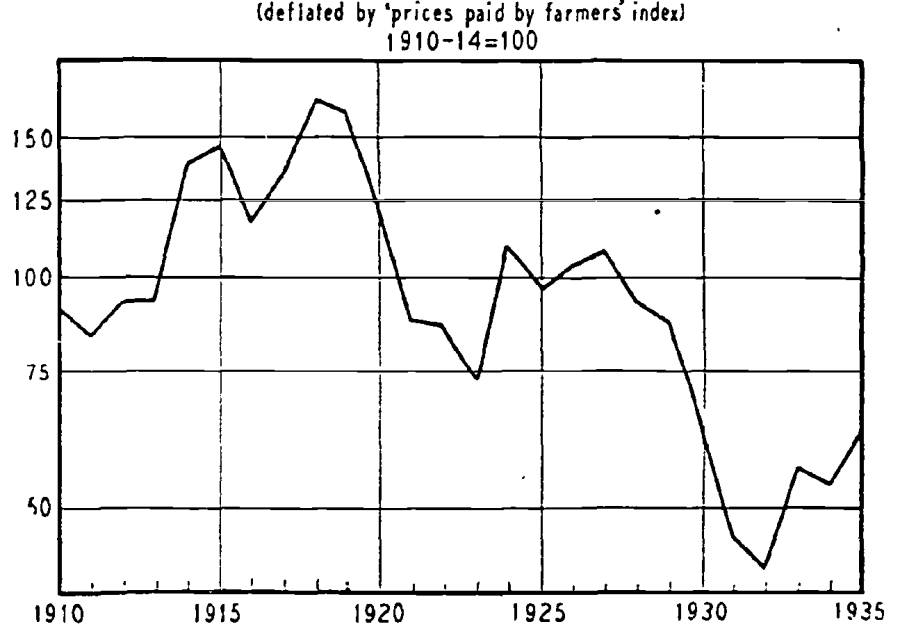

Although the depression in wheat is primarily determin:d by technical progress, additional factors must be taken into account to make the picture more complete and the influence of mechanization more understandable.

\section{Indebtedness and price fluctuations}

This is not the place to evaluate the extent to which the wheat siturtion has been aggravated and accentuated by factors directly connected with the War. It is, however, 
impossible to ignore one important consequence of the War; namely, the inflationary tendencies prevailing throughout the War and part of the post-War period. The general rise in prices undoubtedly had marked effects on the entire farm situation. The sharp increase in farm prices and net income of farmers was accompanied by a steep rise in real estate values. The average price per acre of farm land in the United States rose from $\$ 39.60$ in 1910 to $\$ 69.38$ in $19200^{31}$ Rising prices and rising real estate values greatly stimulated the transfer of farms, and led to an increase in the total farm mortgage debt. Between 1910 and 1920 this debt rose from 3,320 to 7,858 million dollars, or 136.6 per cent. Though the establishment of a causal connection is not fully warranted, it seems significant that the rise was particularly heavy in districts that introduced new methods of production. In Montana, notably, the mortgage debt in 1920 was nearly eight times as high as in 1910 , increasing from 20 to 155 million dollars. Indebtedness in the eight Mountain states rose 379 per cent, in the Pacific states 213 per cent, and in the West North Central states 147 per cent. In contrast, mortgage debts in New England and in the Middle Atlantic states, where methods were not changed greatly, increased only 59 and 41 per cent.

Undoubtedly farm land and improvements purchased at very high prices, when income prospects were favorable, became a heavy burden when prices of farm products dropped. Changes in the general price level were the more burdensome since the average mortgaged farm remained under mortgage 25-30 years or even longer. Many farm mortgages were incurred when interest rates were especially high, not only during the War but also in 1920-21 and 1923-24. As a result these fixed charges absorbed an extremely high percentage of farmers' incomes. In 1925, when 36 per cent of all farms reported mortgages (which,. in the aggregate, constituted less than 20 per cent of the total value of land and buildings), nearly one-third of the net return from all farm land and buildings in the United States was required to meet the charges for mortgage debts on farms." Payments of interest on farm mortgage debts (at 5.5 per cent) in Minnesota constituted 5 per cent of gross sales in 1910, 7 per cent in 1920, 8 per cent in 1925, 9 per cent in 1930, and no less than 16 per cent in 1932."

The influence of this factor cannot be separated from the effects of other forces. There can be, however, no doubt that the disparity between fixed debt service and reduced income severely aggravated the situation of farmers.

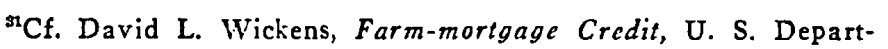
ment of Agriculture, Technical Bull. 288, p. 5.

${ }^{x}$ Cf. ibid., pp. 3, 62.

${ }^{x}$ Cf. E. C. Johnson, Farm Mortgage Foreclosures in Minnesota, University of Minnesota, Agricultural Experiment Station, Bull. 293 , p. 2.
Between 1920 and 1923, 8.5 per cent of all farms were foreclosed or turned over to creditors, and between 1926 and 1932, 17.6 per cent were sold for delinquent taxes, mortgage foreclosures, etc. ${ }^{34}$ Even in 1928, when the farm situation was better than in most post-War years, 4.9 per cent of all mortgaged farms were foreclosed. Thus, there seems good evidence that fixed costs for debt service in a period of changes in the price level contributed heavily to the difficulties of adjusting farm production. ${ }^{35}$ Farmers who specialized in one crop, such as wheat, were worse off than those whose farming was diversified. We cannot measure the extent to which the elimination of certain types of farm has been affected by diffculties resulting from high debt service. No adequate statistics are available that would make it possible to classify indebtedness according to size of farm.

\section{Forcign demand for wheat}

Within a short time after the outbreak of the World War, the new world had to supply a great part of the normal import needs of European countries formerly supplied by Russia and the Danube Basin. . In addition, the chief wheat importing countries had to curtail their domestic production. This situation accelerated the introduction of large scale machinery in the wheat exporting countries, especially the United States, ${ }^{30}$ and consequently speeded up the expansion of acreage and production. The resulting increase in supply was disposed of by greatly increased exports to Europe. Credits to the foreign importer facilitated the disposal of the large wheat crops. But this market for increased North American production was dependent upon an emergency that was not likely to continue when peace returned. The Wartime financing continued to kecp European purchasing power large through 1919. For a short while thereafter commercial export credits could maintain European purchasing power for American farm products. When, however, monetary and general economic disturbances in Europe set in, the export channels suddenly became glutted. The break in farm prices in the middle of 1920 was due to the economic and monetary disturbances in Europe rather than to production changes during the $\mathrm{War}$, for European production

${ }^{34}$ Cf. The Farm Debt Problem, 73d Cong., 1st Sess., House Document No. 9, 1933, p. 27.

${ }^{35}$ The argument advanced in connection with the relation of farm taxes and output also holds true here.

si Such a development might have occurred even without the War. The pre-War trend toward diversification of production in the United States was not favorable to a rapid introduction of large scale machinery. However, competition of other overseas countries, particularly in wheat, was quite strong. This situation would, in any'event, have made it necessary to reduce costs in the United States by a shift to mechanized production in order to meet the competition of Canada and Argentina. 
even in 1920 was still about 30 per cent below the preWar level, and world supply as a whole had just regained this level. The situation was gradually eased with the return of stable conditions in Europe and with the increasing influx of American capital, which for the time being made it possible for European countries to continue to take much of the surplus production of the new world. But, the surplus producing countries were not able to reverse the trend of mechanization. ${ }^{\text {T }}$

For some time after the War demand for these surpluses still existed, although distribution was hampered by unstable conditions in Europe. As the import needs of the old world decreased with increased domestic production stimulated by tariffs, the market situation gradually became less favorable for North American wheat. The increasing difficulties in adjusting the balances of payments of the debtor countries contributed to dislocations in demand: the balances of payments of importers of farm products, notably Germany, necessitated large exports of manufactured products in exchange for agricultural foodstuffs and raw materials. The shift of the United States from a pre-War debtor to a post-War creditor position and the increase in American tariffs aggravated foreign trade conditions for agriculture and thus added to the diffculty in disposing of farm surpluses.

The influence on European purchasing power of dislocations in the balances of payments was felt in two directions: (1) the exchange dislocations were partly responsible for the extension of production in those countries which experienced severe difficulties in settling their balances of payments; (2) bilateral trade grew at the expense of multi-lateral trade.

"Cf. Section I.

\section{Influence of population growth and per capita demand}

To gauge the influence of changes in total demand on the post-War depression in wheat it is necessary to consider shifts in the demand curve for wheat. Before the War population increased continuously. While the percentage increase in the production of wheat exceeded that in population, the relative firmness of wheat prices suggests that per capita demand for wheat increased sufficiently to balance it. ${ }^{28}$

The decrease in population and possible changes in demand during some of the $W$ ar years need not concern us here, since the situation was undoubtedly dominated by the small supply. If changes in demand had any influence on the depression in wheat, they became clear only after the War. Table 13 may help to clarify the point.

In forty countries (excluding Russia, China and Turkey) average population during 1931-36 was 20.3 per cent greater than during 1910-14. Other things remaining the same, this would have meant a proportionate increase in the demand for wheat. But other things did not remain the same. An important variable, which however we can estimate only very roughly, was the changing per capita demand for wheat. As Table 13 shows, per capita consumption in the United States decreased some 13 per cent. We may argue that because of the high standard of living in the United States, this decrease is not greatly dependent on factors of supply but represents largely actual shifts in per capita demand (assuming, of course, ex-

${ }^{a}$ It is assumed that the supply curve for wheat did not rise. What we know of the changing conditions of production in wheat and of industrial production and demand suggests that in fact the supply curve may have fallen, which strengthens the above argument.

TABLE 13

Whe.IT CONSUMPTION DURING 1910-1914 AND 1931-1936

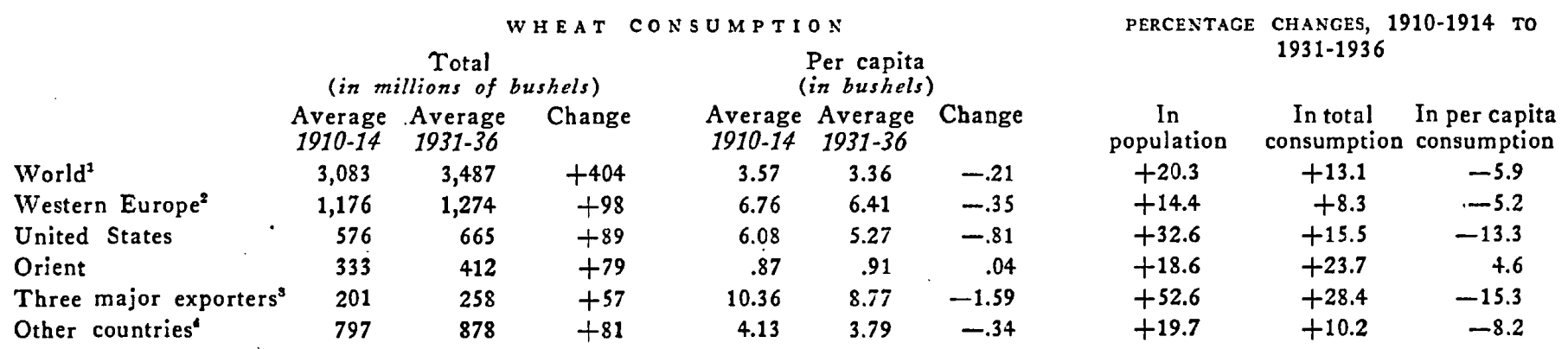

source: M. K. Bennett, World Wheat Utilization since 1885-86; Wheat Studies of the Food Research Institute, Vol. XII, No. 10, June 1936.

${ }^{1} 40$ countries (Russia, China and Turkey excluded).

${ }^{3} 12$ countries: Great Britain, Irish Free State, France, Italy, Spain, Portugal, Belgium, Holland, Switzerland, Denmark, Norway, Sweden.

${ }^{8}$ Canada, Australia, Argentina.

'21 countries: Germany, Finland, Estonia, Latvia, Lithuania, Poland, Czechoslovakia, Austria, Hungary, Jugoslavia, Rumania, Bulgaria, Greece, Algeria; Morocco, Tunis, Egypt, South Africa, New Zealand, Chile, Uruguay. 
tremely inelastic demand). There can be little doubt that actual per capita demand the world over has not declined as much as it has in the United States. But even if we assume, as an extreme case, that world per capita demand also declined 13 per cent, it is still obvious that there cannot have been a decline in the demand curve for wheat; there must have been a rise. The increase in population, 20.3 per cent, more than balanced the assumed decline in per capita demand, 13.3 per cent. There is consequently little ground for saying that the change in total demand for wheat after the War was a positive factor in bringing about the depression in wheat. ${ }^{2}$ However, since the population movement of the last decade indicates a strong possibility that the growth of world population will in the future be insufficient to counterbalance a continued decline in per capita demand, the demand factor may become an important determinant of future conditions.

The influence of consumption on the wheat depression may be considered from another angle. Is it significant that population and per capita consumption did not follow the pre-War trend? Had the pre-War trend continued, total annual consumption 1931-36 would have been 9.5 per cent above the actual consumption, according to computations of the Food Research Institute. There is, of course, no reason to believe that wheat farmers planned production after the War, confident that consumption would follow the pre-War trend. But even the argument that the maintenance of the pre-War trend in consumption would have checked the formation of excessive stocks would, probably, misrepresent the situation. Had total consumption followed the pre-War trend, the movement of wheat prices rould have been more favorable to wheat producers, disregarding for the moment the wheat policy of the European importing countries. The advantages of large scale mechanized wheat farming disappear if the price of wheat falls below a minimum determined by overhead costs. If the price had moved above this critical point, large scale farming would have expanded far above the present level ${ }^{\omega}$ in certain districts of the United States as well as in Canada, Argentina and Australia. Moreover, a period of high prices would have facilitated the

${ }^{*}$ It is also impossible to establish a direct influence of the industrial depression on world consumption of wheat and on wheat farming. In some countries, however, in which the standard of living is relatively low, the depression starting in 1929 seems to have contributed to a decline in consumption. In the abovequoted study of the Food Research Institute, Mr. Bennett states that in some countries-Germany, Austria, Italy, and parts of eastern Europe-the reduction in employment and income during the industrial depression resulted in decreased consumption of wheat and shifts toward cheaper cereals.

${ }^{\infty}$ As shown above, the period $1920-29$ is distinctive in that wheat production was mechanized and expanded particularly when prices were favorable to large scale mechanized farms. acquisition of machinery and the expansion of acreage for the reason that higher farm incomes as well as better credit opportunities would have prevailed. The consequences of such a situation would probably have been a greater expansion of total wheat acreage than was actually experienced. There is no reason to believe that under these hypothetical conditions an ultimate depression would have. been avoided.

\section{Implications}

Demand factors may have been partly responsible both for the timing of the outbreak of the wheat depression and for its accentuation. Let us now attempt to evaluate the prospects for the future utilization of wheat, and their bearing upon the problem of overcoming the depression.

The decline in wheat imports of the former wheat importing countries, particularly of western Europe, is due to various causes. The most important is certainly the increase in wheat acreage and production in these countries, arising from the desire to protect the farmer or to prepare for war, and, not least, from the necessity of meeting foreign trade and foreign exchange difficulties. These incentives to home production may not be so strong in the future; if not, per capita consumption, especially in those countries whose standard of living is low or moderate, will rise when domestic wheat prices fall. From a short term point of view such an occurrence may be quite important for the mitigation of the world wheat crisis, but it could not solve the wheat problem in the long run. As we have tried to show, the crucial feature in the wheat depression is supply. Adverse climatic conditions, as in the drought years 1934 and 1936, play a role in improving the wheat situation and lowering stocks for a short time. These circumstances, as well as the immediate effect of the depression on wheat farmers in all size groups, may retard and delay a further resort to mechanized production with its concomitant increase in output. In the long run, however, mechanization will undoubtedly progress. Acreage and production will tend to increase and the elimination of farmers may be expected to continue. We can therefore hardly state that the depression in wheat has been definitely overcome.

The prospects for a notable increase in demand for wheat are few. A change to a liberal agricultural and tariff policy in France, Germany and Italy (which is not very probable) may lead to an increase in per capita consumption. Wheat consumption in the Orient may also increase, if political and economic conditions improve. On the other hand, in countries with a high standard of living consumption will decline further. In the long run this factor may become important. According to a study of the Department of Agriculture, the attainment of a liberal ('ideal') diet would cut present per capita consumption of 
wheat flour about half. ${ }^{1}$ One would be very optimistic indeed to expect under such conditions a solution of the wheat problem from the demand side.

\section{B. OTHER FACTORS IN THE COTTON DEPRESSION}

The analysis of the role of mechanization in cotton farming brought to light no evidence that dislocations could have led to a slow process of adjustment and thus to a long depression. Cotton supply was not dependent upon expansion of production as a result of mechanization. Instead, production seemed to be influenced especially by boll-weevil damage and attempts to compensate for it by expanding acreage. It we exclude the effect of these influences on the well-being of cotton farmers, the hypothesis seems plausible that their income is greatly affected by fluctuations in consumers' incomes and in industrial production, i.e., by the course of business cycles. It would imply that depressions in cotton farming may be caused by industrial depressions and that fluctuations in cotton farmers' income are short. Is this hypothesis confirmed by the movement of cotton farmers' income?

To find a series adequately representing the income of cotton farmers is as difficult as it was to find one showing the prosperity of wheat farmers. The series of net income of cotton farmers and per capita purchasing power of net income from cotton, contained in a study on the cotton farmer's position, by Philip $\mathrm{H}$. Bollinger under the direction of $L$. $H$. Bean, seems the best available."

Net income was calculated by deducting estimated cash costs of production from farm income derived from lint and seed. This series was deflated by the cost of living index of cotton farmers. A second series was selected expressing per capita purchasing power of net income from cotton. Owing to the relatively small changes in the number of cotton farmers as compared with crop, price and expense changes, this second series closely parallels the first, as Chart 8 shows. Despite possible limitations, these series indicate roughly the changes in the economic situation of cotton farmers. If we assume that the average for 1910 14 fairly represents normal conditions in cotton farming, conditions more favorable than normal prevailed in four years between 1920 and 1934. Except in 1923-25 and

"Hazel F. Stiebeling and Medora M. Ward, Diets at Four Levels of Nutritive Content and Cost, U. S. Department of Agriculture, Circular 296, 1933.

-Cf. Agricultural Adjustment Administration, Program Planning Division, Agricultural Industrial Relations Section, U. S. Department of Agriculture; Cotton, Facts relating to cotton prices and purchasing power, out-of-pocket cost of production, net farm income from cotton and purchasing power of income, relation of net income from cotton to national income and other data bearing on the cotton farmer's economic position; prepared by Philip $\mathrm{H}$. Bollinger under the direction of L. H. Bean, Washington, V. C., August 1935.

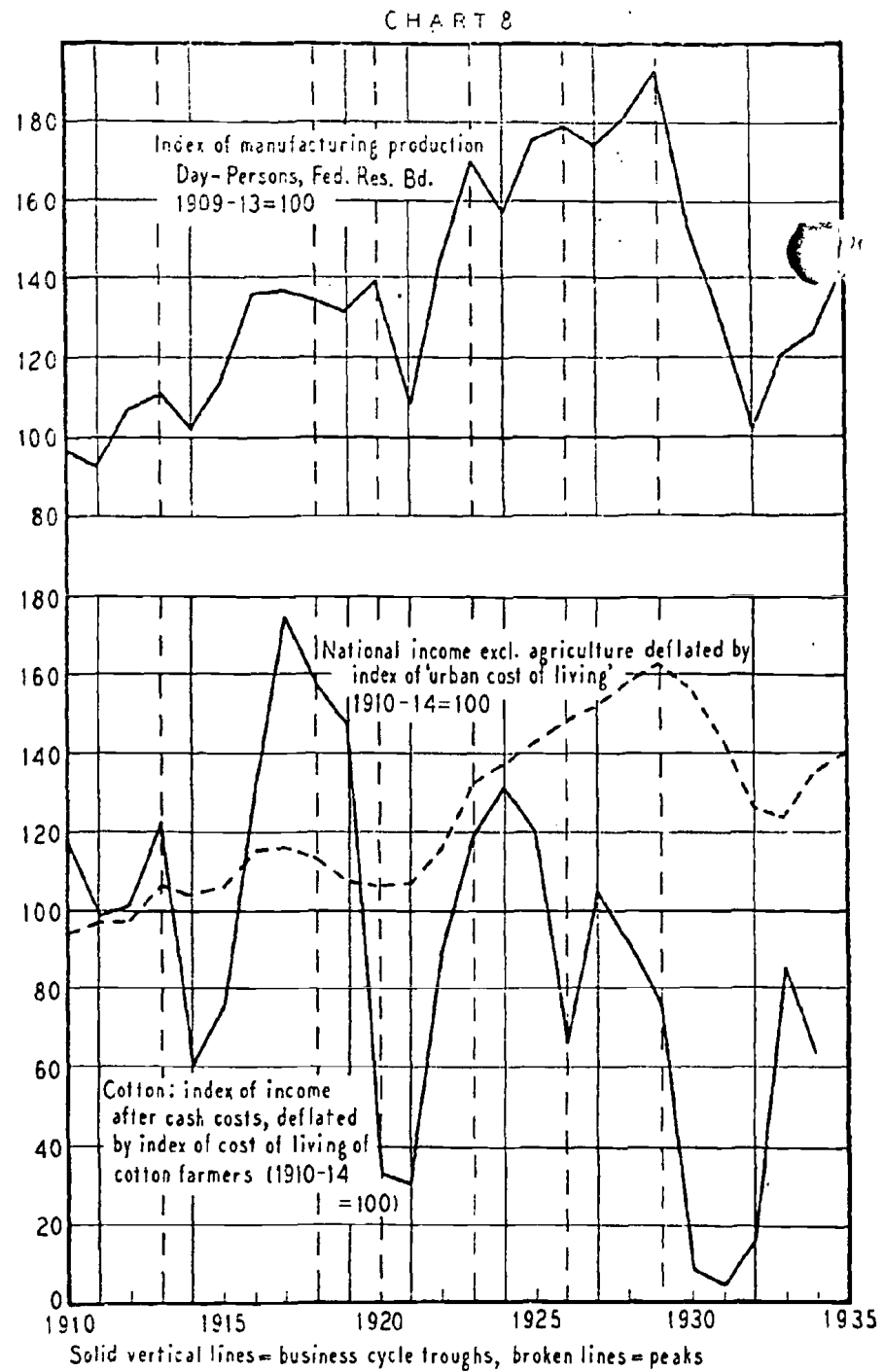

1927, net income of cotton farmers was much below 191014. This becomes even more apparent if we compare cotton farmers' income with non-agricultural income, the latter deflated by an index of urban cost of living.

It is possible that the social system of cotton farming and the fact that much of the cotton acreage represents marginal land ${ }^{4}$ under conditions prevailing during most of the post-War period contributed to the depressed situation of cotton farming. But this is hardly an adequate explanation. Undoubtedly these factors greatly influenced the position of cotton farmers after the $W$ ar but it is impossible to attribute the post-War situation in cotton farming solely or predominantly to them. If there was a long depression in cotton farming, which is by no means tain, we are not able to give a satisfactory explanation or its origin.

${ }^{4} \mathrm{Cf}$. W. W. Ashe, Marginal Land and Cotton Prices, Journal of Farm Economics, October 1931, p. 590: "Possibly as much as 10 per cent of the present crop was produced upon land which is marginal under existing economic conditions and with present standards of living." 
The hypothesis that the position of cotton farmers depends upon fluctuations in general business activity calls for some consideration. As an indicator of general business fluctuations, the Day-Persons Index of Manufacturing Production was chosen, supplemented from 1930 on by monthly averages of the Federal Reserve Board Index of Manufacturing Production. Cotton farmers' net income rose from 1921 to 1923 with manufacturing activity. However, during the industrial upswings of 1924-26 and 1927-29, it fell sharply. Thus, comparison of net income of cotton farmers and manufacturing activity hardly substantiates the hypothesis that total net income of cotton farmers is dependent on business activity within the United States.

Business conditions in the United States apparently do not control total income of cotton farmers. This may be due to the fact that roughly half of the American cotton crop is exported and that the amount exported is determined by factors other than general business conditions in the United States. We therefore separate total income of cotton farmers into income derived from exports and income derived from domestic consumption (again based on the computations of Messrs. Bollinger and Bean). The movement of gross income from cotton lint consumed in the United States (Chart 9), together with the movement of income from cotton lint exported and the DayPersons-Federal Reserve Board Index of Manufacturing Production, reveals a picture that is very different from the observation based on total income of cotton farmers. During both 1921-23 and 1927-29 income from domestic lint consumption moved upward with business revivals, the increase in income from domestic consumption starting one year before the business revival, 1927. To test the conformity indicated by yearly figures we analyze monthly data of cotton consumption in American mills. It is clear that the non-conformity of total income of cotton farmers and business conditions in the United States is largely due to the movement of income derived from exports. Therefore, it is essential to consider separately the conditions underlying domestic consumption of raw cotton and the factors determining foreign demand for American cotton.

\section{Domestic Demand for Cotton}

The utilization of cotton as a raw material for clothing, household and industrial goods is rather closely connected with industrial production and with cyclical fluctuations in the incomes of the industrial population. The dependence of demand for cotton on the industrial cycle is determined by several factors and hence is not clear cut. There are few statistics available that separate the percentage of cotton used for clothing and household purposes from that used for industrial purposes." The indications are, however, that there is a decided trend toward an increase in

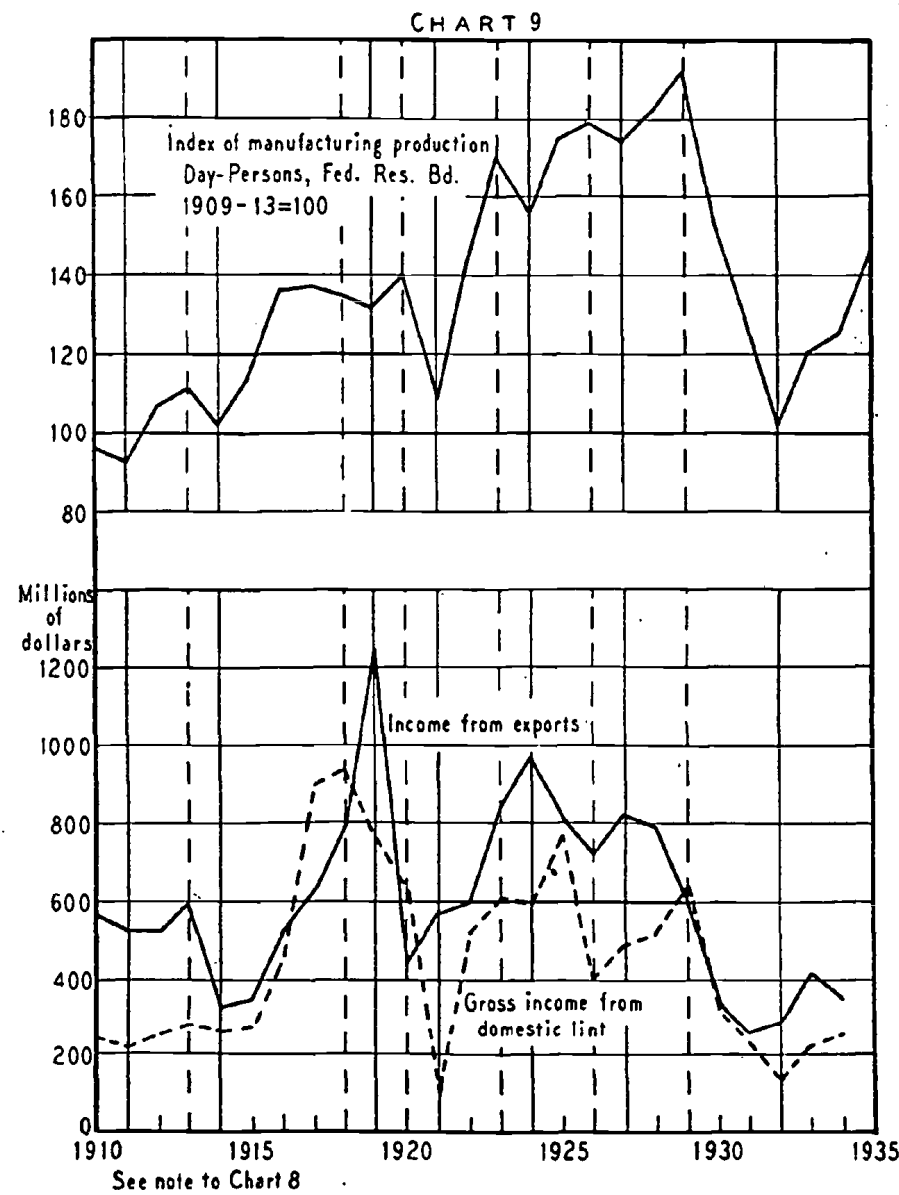

the industrial use of cotton in the United States; consumption for clothing and household use has declined. The Department of Agriculture estimates the yearly domestic mill consumption (which represents the total use of cotton) at 26.3 pounds per capita in the five-year period ended 1909-10, as against 26.2 pounds during the five-year period ended 1930-31. In the later period an equivalent of 3.2 pounds per capita was used in the production of automobiles and casings alone, a negligible item in the earlier period. In a year of high industrial production, as 1929, about "For 1924 the percentage of cotton piece goods used for industrial purposes (manufacture of furniture, awnings, shoes, mattresses, tires, etc.) was estimated at 30 ; cf. Distribution of Textiles, Bureau of Business Research, Harvard University, Bull. 56, p. 155. Of total 1929 production of cotton fabrics, yarns and felts amounting to 8,500,000,000 square yards, 2,200,000,000 were used chiefly for garments, 1,500,000,000 chiefly for household goods and 1,100,000,000 for one of these two purposes, whereas $3,700,000,000$.were destined for other purposes, i.e., in 1929, 43 per cent of the production was used for industrial purposes. Cf. Report of the National Survey of Potential Product Capacity, prepared under the sponsorship of the New York City Housing Authority and Works Division of the Emergency Relief Burcau, City of New York, 1935, p. 111.

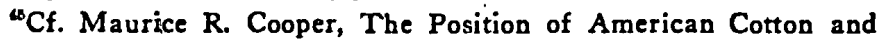
the American Cotton Producer, Address, 9th Annual Marketing School, Little Rock, Arkansas, March 4, 1936 (U. S. Department of Agriculture), p. 11. 
10 per cent of the entire cotton consumption of the United States was absorbed by the automobile tire industry, and another 3 per cent was used by the automobile industry proper for car tops, upholstery, brake bands, etc." Consumption of cotton for various other industrial purposes has also increased, making cotton consumption more dependent upon industrial fluctuations. The decline in per capita consumption for clothing and household purposes is due mainly to changes in style and to competition of other textile materials. The growing competition of other materials may be indicated by the rise in rayon production, which averaged 20 million pounds in 1910-14 (world production) and 775 million pounds in 1934. The pre-War production of rayon equaled, on a pound per pound basis, 40,000 bales of cotton as against $1,600,000$ bales in 1934, which corresponds to 30 per cent of American mill consumption. The rise in American rayon production is even more startling. Before the War production was negligible; it is now about $250,000,000$ pounds. ${ }^{.7}$

The character of the fluctuations in the demand for raw cotton depends upon the use to which it is put. Demand

${ }^{*}$ Cf. Yearbook of Agriculture, 1933, p. 105.

:On the other hand, the increase does not mean a net loss to cotton since rayon production contributes to the demand for cotton (in 1929, 61 million pounds of cotton linters were used in the American production of rayon, according to the Census of Manufactures). for clothing, still the most important item even in the United States, is substantially affected by changes in consumers' incomes, which follow the industrial cycle. Approximately the same relation holds for changes in demand for household cotton goods. Cotton consumption for industrial purposes is less dependent upon cotton prices than upon the situation of those industries which use cotton. The demand of industries using cotton as a subsidiary material depends upon fluctuations in their output. Even the demand of industries in which cotton as a raw material constitutes a large percentage of the total costs of the final product, such as the automobile tire industry, fluctuates with business cycles. These too general statements referring to the demand for cotton may be supplemented and tested br an analysis of the behavior of various cotton consuming industries during business cycles.

Total mill consumption is determined by the activity of several industries using cotton as a raw material. In order to gauge the complexity of demand fluctuations in these various industries, we analyze production in two representative industries: textiles and automobile tires. We take, in addition to total mill consumption: (a) billings of finished cotton goods, ${ }^{29}$ as an indicator of the fluctuations

"The billings of finished cotton goods are approximately synonymous with production, goods being billed as completed and the data being expressed in yards, not values. The series is based on compilations of the National Association of Finishers of

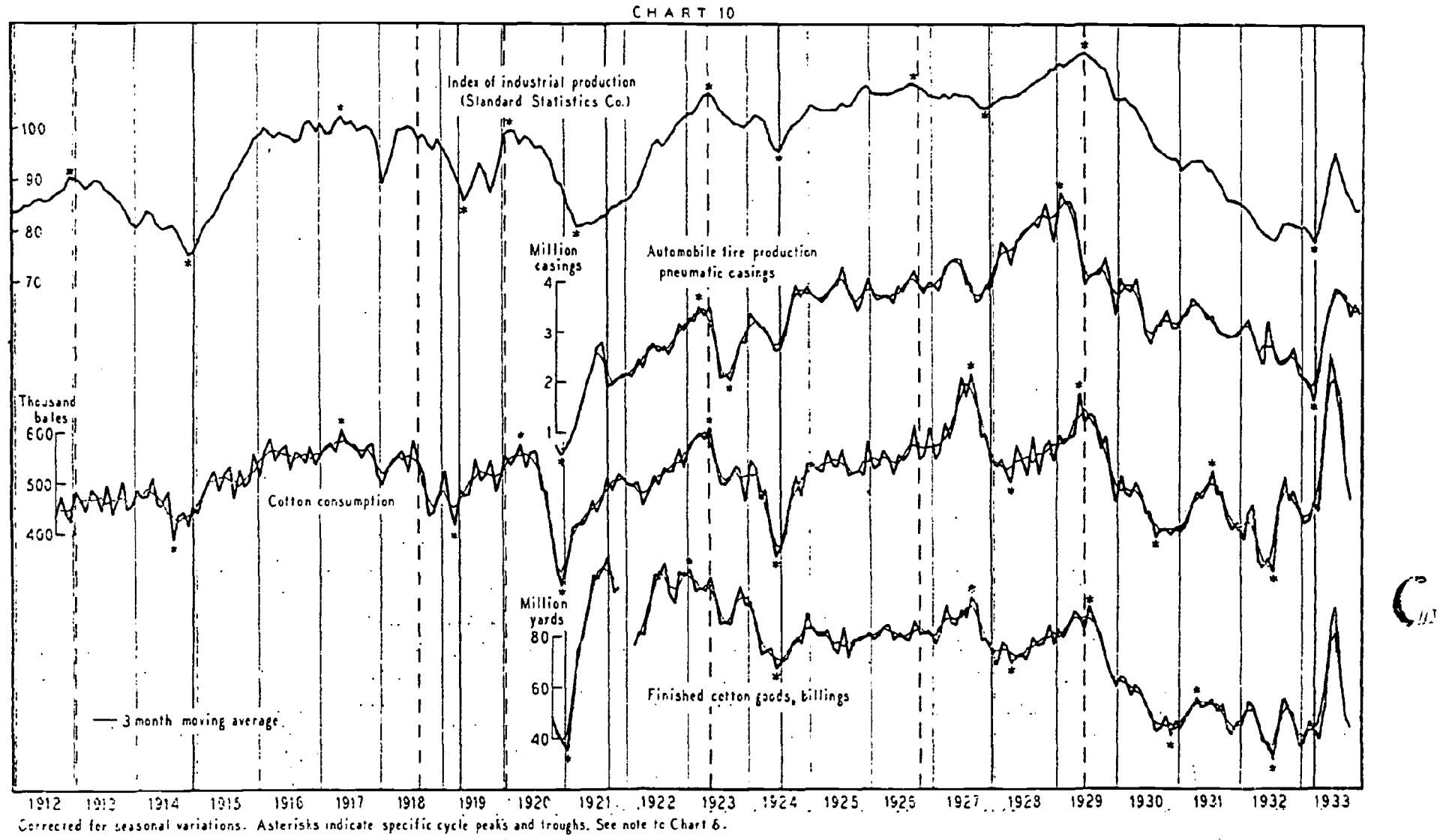


in cotton consumption for clothing and household purposes; (b) the production of automobile tires (pneumatic casings) as an indicator of the other industrial uses of cotton (Chart 10). The dark lines refer to the seasonally corrected figures, the dotted lines represent threemonth moving averages. The addition of a fourth series, the Standard Statistics index of industrial production, facilitates a comparison of the three series expressing activity in industries using cotton with general industrial activity. In order to make clear the movement of these four series during business cycles, the troughs of business cycles are indicated by black vertical lines, the peaks by dotted vertical lines. The timing of business cycles is based on Professor Mitchell's chronology." The peaks and troughs of the four series here analyzed are marked by asterisks.

Most significant is cotton consumption by mills, since it indicates total industrial consumption of raw cotton. During the period here analyzed six cycles of cotton consumption can be observed, which up to 1928 correspond fairly well with general business cycles. During the latest business cycle, which started in January 1928, reached a peak in June 1929 and ended in March 1933, however, cotton consumption experienced an extra specific cycle. This extra cycle must be attributed chiefly to variations in demand. Doctors Mitchell and Burns explain that replacements of such semi-durable necessities as textiles become necessary after a year or two and that therefore any contraction in their production lasting more than about two years will be followed by moderate upturns. ${ }^{80}$

A tendency for cotton consumption to lead at business crcle troughs is noticeable in five out of six cycles observed. Finished cotton goods (billings) move similarly to cotton consumption by mills. This series also reveals an extra cycle during the latest business cycle; the timing, particularly in respect of the troughs, is very close to that of the latter series. Automobile tire production (pneumatic casings) is strongly affected by the sharp upward trend of automobile production during the first decade after the War and by the shift from solid tires and cushions to pneumatic casings. Thus, tire production declined only

Cotton Fabrics. White goods and dyed goods comprise each about 40 per cent of total billings, printed goods about 20 per cent. The series can be considered representative of total production of the industry; white goods in the series amounting to 70 per cent, dyed goods to 55 per cent, and printed goods to 25 per cent of total production of each type.

${ }^{\circ}$ Cf. Wesley C. Mitchell, Business Cycles, Vol. II, Analysis of Cyclical Bchavior (a preliminary mimeographed draft of Chapters I and II, p. 40, National Bureau of Economic Research, Novermber 1935).

${ }^{50} \mathrm{Cf}$. Wesley C. Mitchell and Arthur F. Burns, Production During the American Business Cycle, 1927-1933, National Bureau of Economic Research Bull. 61, p. 18. slightly during the business contraction of 1926-27. Nevertheless, the influence of business cycles on tire production is clear.

For the period that the various series cover, the evidence points strongly toward a fairly close dependence of the fluctuations of cotton consumption in the United States upon the course of business cycles. It is not necessary to analyze here the relations for individual cycles. The rise during business expansions and the fall during contractions (with the modifications mentioned and explained and the provision for leads and lags) stand out so clearly that the domination of these series by business cycles cannot be doubted. This does not mean that no other factors affect the extent and timing of the fluctuations in demand for cotton. But it does suggest that a rise in cotton consumption can be expected in the course of business expansions and that consumption is adversely affected by business depressions.

\section{Foreign Demand}

Cotton is a staple product with a world market. From one-half to two-thirds of total American production was consumed in foreign countries during the last two decades. ${ }^{\text {.t }}$ The share of foreign consumption in total production of American cotton is illustrated in the accompanying table. ${ }^{62}$ These percentages mean that the demand for American cotton is influenced as much by consumption in foreign countries as by consumption in the United States, if not more.

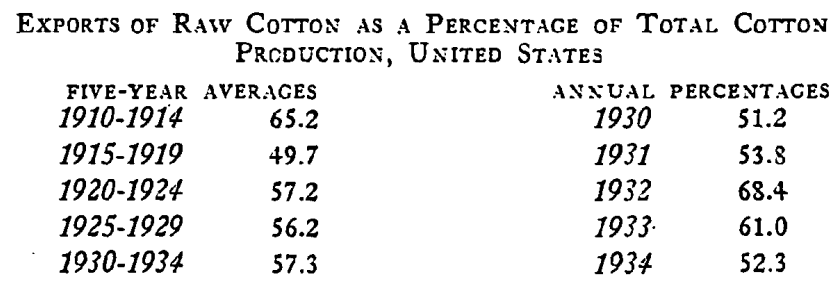

Three factors may be regarded as determining foreign consumption of American cotton. (1) General business conditions in countries importing American cotton. (We should note, however, that the relation of demand to domestic business cycles in the main importing countries, particularly in the highly industrialized European countries, is less close than in the United States, because they export a higher percentage of their yarns and finished cotton goods.) (2) Structural changes in the world cotton manufacturing centers. (3) The competition of American cotton with foreign grown cotton which takes place almost exclusively in foreign countries using American cotton.

Since the War the influence of the domestic business situation on cotton consumption in important industrial ${ }^{5} \mathrm{Cf}$. Section $\mathrm{B}$, Other Factors in the Cotton Depression. ${ }^{50}$ Production and export figures, cf. U. S. Department of Agriculture, Agricultural Statistics, 1936, pp. 75-76. 
countries has been overshadowed by structural changes in the cotton industry and markets. The expansion of the textile industries of oriental countries limited the export possibilities particularly of Great Britain, the most important consumer of American cotton. The increasing capacity of oriental cotton mills, which use much less American cotton, is shown herewith.

\begin{tabular}{|c|c|c|c|c|c|c|}
\hline & \multicolumn{6}{|c|}{ EXPANSION OF THE ORIENTAL COTTON INDUSTR $x^{2}$} \\
\hline & $\begin{array}{l}\text { Spindles } \\
2,365,000\end{array}$ & $\begin{array}{l}\text { Looms } \\
25,400\end{array}$ & $\begin{array}{l}\text { pindles } \\
983,000\end{array}$ & $\begin{array}{r}\text { Looms } \\
9,400\end{array}$ & & $\begin{array}{l}\text { Looms } \\
106,500\end{array}$ \\
\hline & & 44 & & & & 11 \\
\hline & 987,000 & 77,850 & $1,224,000$ & 29,300 & $, 125,000$ & 129,0 \\
\hline
\end{tabular}

${ }^{1}$ Cf. Royal Institute of International Affairs, Notes on the Textile Industry in Lancashire, India, China and Japan, March 1933.

The shifts in cotton manufacture from occidental to oriental countries continued after the world depression, as a comparison of data for 1935 and 1925 shows : increase in spindles of 106 per cent in Japan, 45 per cent in China and 21 per cent in India contrast with decreases of 29 per cent in Great Britain and 21 per cent in the United States. Between 1913 and 1932 the number of spindles in Asiatic countries increased from 7 to 13 per cent of the world spindleage; Asiatic cotton consumption increased from 19 to 35 per cent of world consumption.

Shifts in the capacity and consumption of the cotton industries affected not only conditions in cotton mills, especially of European countries, but also the export of American raw cotton. Oriental mills depended largely upon Egyptian and Indian cotton; European mills consumed

${ }^{\text {sa }}$ See the computations of Leonard G. Ting, Recent Developments in China's Cotton Industry, Nankai Social and Economic Quarterly, Vol. IX, No. 2, July 1936, p. 398. mostly American raw cotton. The changes in the use of the various grades of cotton during the post-War period are not due exclusively to shifts in the cotton industries. The decrease in purchasing power due to the industrial depression in the various countries and foreign exchange difficulties led to an increasing consumption of the cheaper

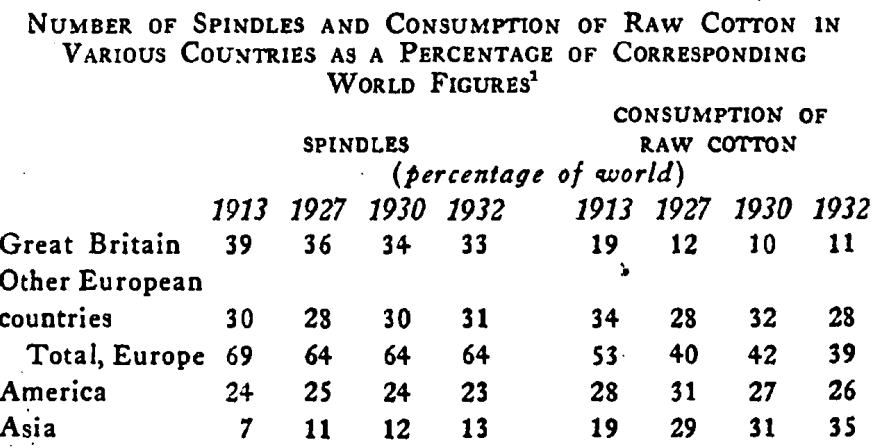

International Cotton Bull. 41, October 1932, The Depression in the European Cotton Industry, Lugano, p. 17.

short staple qualities grown in foreign countries." Though it is not possible to determine the relative influence of each factor, their importance is seen in the changes in the consumption of American, Egyptian and Indian cotton in important cotton manufacturing countries (Chart 11).

In the United States, consumption of foreign grown cotton is still negligible; fluctuations in consumption are almost exclusively in domestic cotton. Most striking are the changes in consumption on the Continent. The 1910-

suearbook of Agriculture, 1932, p. 100.

ss It may be noted that the purchase of cotton on a barter or compensating trade basis has been of some significance in increasing the consumption of foreign growths at the expense of American cotton during the last few years.

CHART 11

TOTAL CONSUMPTION OF COTTON, BY TYPE
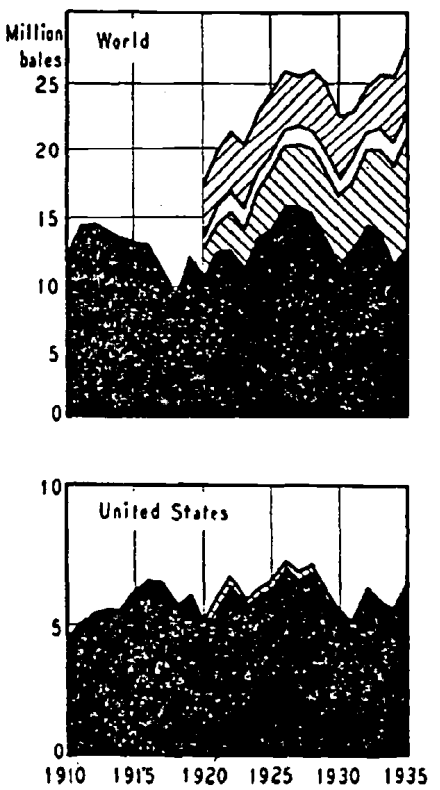

American

15 Sundry"

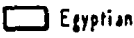

EDIian

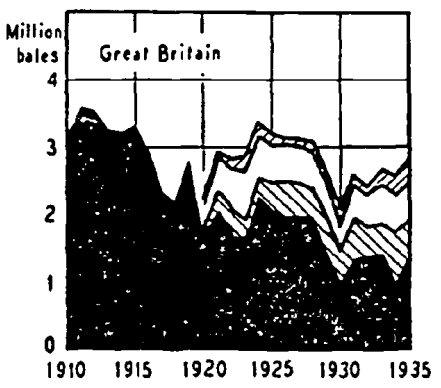

* Sundry cerens, eacept in the case of the United Slates mere il represents oll non Americon settons.
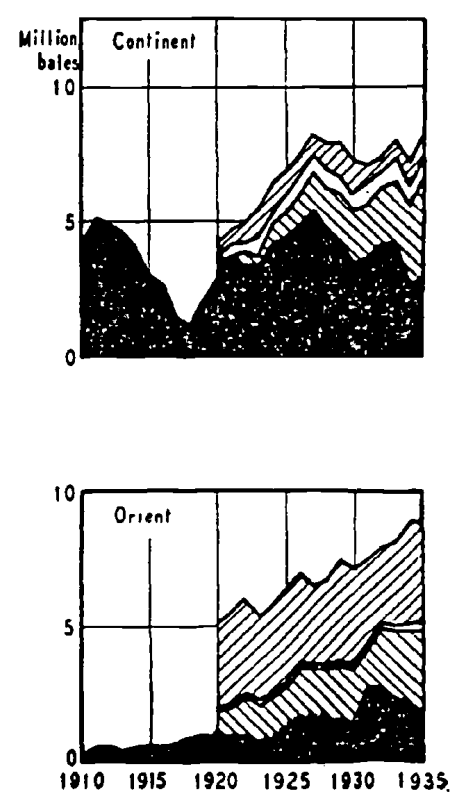
14 peak in consumption of American cotton has been surpassed only once, in 1927, and then slightly. After a continuous rise from 1917 to 1927 (interrupted by slight declines in 1922 and 1923) the consumption of American cotton declined except between 1930 and 1933. Until 1927 fluctuations in total continental consumption were : " due to changes in consumption of American cotton. Exen during this period a tendency toward increasing consumption of Oriental cotton is noticeable. After 1927 the decrease in consumption of American cotton was about compensated by increasing consumption of 'sundry' cottons (mostly Chinese), with consumption of Indian cotton also decreasing. Consumption of cotton in England is marked by a conzinuous decline between 1924 and 1930, and by a declining proportion of American cotton to total consumption. Oriental consumption moved sharply upward after the War. The peak of world consumption of American cotton was reached in 1932 . The increasing importance of Chinese cotton is apparent. Owing to a sharp increase in consumption of 'sundry' cottons, American cotton contributes now less than one-half to total world consumption.

\section{Summary}

Under present conditions supply cannot be regarded as decisive in the cotton depression. Cotton production can be adjusted to changes in demand more readily than can wheat production, although the perfection of the cotton picker would probably bring far-reaching changes in this respect. An important factor affecting the cotton situation is general business activity in cotton consuming countries. Income of cotton farmers can be expected to rise during business revivals.

\section{c. INDIRECT EFFECTS OF MECHANIZATION}

Though mechanization and changes in the farming system are most advanced in wheat, mechanization is by no means limited to wheat. It forced widespread shifts upon American agriculture as a whole: the replacement of work animals by tractors and automobiles reduced the needs for feed and thus the amount of feed crop acreage.

This substitution must be considered as a factor contributing to the difficulties of agriculture in general, especially at a time of severe dislocations in the farming system." The transference to manufacturing industry of activities for rly regarded as belonging to agriculture is no novel the The narrowing range of farm activities explains in large degree the migration of part of the farm population to the cities. But probably never before has the replace-

"This is not an appraisal of the 'net' effects. The effects on industry and the adrantages resulting from reductions in costs for certain farm products need not be considered here. ment of typical farm activities by industrial processes been so rapid and far-reaching as after the introduction of the tractor. Dr. O. E. Baker of the Department of Agriculture has recently computed data of displaced acreage which show that the decline in horses and mules on farms started with the introduction of tractors during the War; after 1920 it became more rapid. The replacement of horses by the automobile and the tractor on farms was responsible for a release to other uses of 30 million acres of crop land and over 31 million acres of pasturage between 1915 and 1936. If we compare these figures with the crop land harvested and total pasturage in the United States (according to the Census of 1930, 359 million acres of crop land were harvested and there were 379 million acres in total pasturage) we can easily gauge the importance of this factor; nearly 10 per cent of total acreage and pasturage was released through the replacement of draught animals by mechanical devices. At the same time the number of horses in American cities also dropped sharply. This decline started in 1910; between 1915 and 1936 it resulted in a further release of over 12 million acres of crop land. The importance of the release, during 1915-36, of 42 million acres of crop land harvested may be better illustrated if we consider that this acreage approximately corresponds to the total expansion in acreage during the World War, or that it falls short by only 15 per cent of equaling the 50 million acres needed for the record exports of wheat, other cereals, tobacco and cotton in 1921 . Obviously the necessity of shifting the use of these $42 \mathrm{mil}$ lion acres was an additional hardship to farmers. The adjustment to this change, consisting mainly in a shift toward increased production of meat and milk, was complicated by the fact that it coincided with the changes in farm organization brought about by mechanization."

We have noted that one effect of the mechanization process was to put pressure on some wheat farmers to grow other crops. Apparently they had insufficient capital reserves to compete with large scale mechanized farms, or their farms were not adapted to mechanized methods. However, they could overcome these disadvantages by growing crops in which "mass production is either tech-

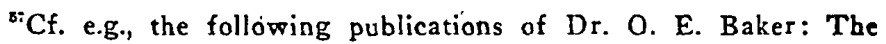
Outlook for Land Utilization, Journal of Farm Economics, Vol. XIII, No. 2, April 1931, p. 214; Agricultural Implications of the Population Prospect in the United States, Procecdings of the Third International Conference of Agricultural Economists (London, 1935), p. 274; The Future Need for Farm Land, Address at Farm and Home Week, Iowa State College, Ames, Iowa, February 9, 1934; revised August 1934, p. 17. "Most of these 37 million acres more or less are now being used for the production of meat and milk." 
nically impossible, or economically does not pay." shifts contributed greatly to the expansion of dairy and meat production; consequently the depression in these branches of agriculture became more severe. ${ }^{\infty}$

\section{Reflections on the Agricultural Depression}

The following remarks are based partly upon the evidence presented in this Bulletin, partly on the research that supplies the background for the entire study. To some extent the opinions expressed are tentative.

The outstanding characteristics of the latest agricultural depression are its length and severity. The situation in wheat was most striking. In its specific form of a long run phenomenon the agricultural depression appears as a tedious process of adjustment, apparently made necessary chiefly by rapid changes in technical conditions that led to a notable expansion in production and a sharp decline in prices.

The latest agricultural depression is by no means a uniform phenomenon. Even in wheat, where depression was fairly continuous, a few years were not so bad. While cotton farming also may possibly be regarded as depressed since 1920, the leading causes were different from those that affected wheat growing. In dairying, it is doubtful whether we can speak of a grave depression.

Two questions arise: (1) What is the justification for considering the agricultural depression as a whole? (2) Why does the depression assume different forms from one branch of farming to another?

$A$ priori, there is no logical basis for regarding the 'agricultural depression' as a unit. But the severe decline in wheat prices forced many farmers to shift to other branches of farming, which were less depressed and not subject to the competition of more advanced techniques, and which produce goods having higher elasticity of demand. Such shifts were noticeable before the depression, but they were accelerated and accentuated by the depression in wheat.

In the course of the post-War industrial depression these other branches also suffered from decline in urban incomes. Even if these repercussions had not been of

${ }^{58}$ Cf. George Pavlovsky, The Cause of the Agricultural Depression in 1931-32, International Institute of Agriculture, Monthly Bulletin of Agricultural Economics and Sociology, 1933, No. 1. Dr. Pavlovsky refers to the shifts in farming made by European farmers. to avoid oversea competition.

${ }^{\text {so }}$ The situation in dairy farming is analyzed in a forthcoming book by the senior author. For the United States it was found that the prosperity of dairy farmers depends largely upon general business conditions, which affect not so much the volume of consumption as prices and consequently total incomes of dairy farmers. major importance, the coincidence of the long run depression in wheat with depressed conditions in those branches which are influenced by changing business activity seems to justify the term 'agricultural depression' for the postWar period. This is more true if we take into account other relations among the various branches of farming.

There is little doubt that the disturbances in wheat were due in large measure to rapid changes in production methods. In wheat, mechanization was carried through on a large scale and the effects of the rapid expansion of production were oversupply and falling prices. The decline in prices was especially sharp because of the inelastic demand for staple foods. The declining trend of wheat prices is due to the predominance of these long run factors.

Why does the adjustment process initiated by technical changes not take place immediately without causing severe disturbances? Technical changes are going on continuously, and indeed for decades the adjustment to such minor changes may leave the agricultural economy undisturbed. But rapid changes make adjustments very difficult because of the peculiarities of farming. Wheat is the outstanding example at present.

In cotton, mechanization is still in its beginning. But even a sudden change in production methods would have consequences that would differ from those in wheat; other things being equal the adjustment process would be much shorter, because of the higher elasticity of demand for cotton. Since the $W$ ar changes in production methods have played only a minor part in the cotton situation, while fluctuations in domestic industrial consumption and in foreign demand have been important.

There is no evidence that long run depression in agriculture is a regularly recurrent phenomenon. The task of theory is to determine the conditions under which a depression in this sense can be expected. Rapid technical progress is a decisive, but not a sufficient condition. From the evidence of the latest depression, such factors as a sharp rise and subsequent decline in real estate values, high indebtedness on account of this situation, difficulties in international trade and exchange such as those following the War, may well be regarded as aggravating conditions.

The agricultural depression began nearly a decade before the great industrial depression. The preceding analysis suggests that we cannot expect the agricultural depression to end soon, so far as wheat is concerned, although it may be alleviated for short periods. The end of the difficulties for wheat depends upon two conditions: either the level of production in the leading wheat producing countries will have to be reduced, or demand must increase notably. There is little evidence that demand will increase to any extent. And any temporary rise in wheat prices is likely to stimulate further mechanization. 